\title{
Türkiye Tarımsal Yüksek Öğretiminin ve Tarla Bitkileri Bölümünün Durumu
}

\author{
Cemalettin Yaşar ÇiFTÇi \\ Ankara Üniversitesi, Ziraat Fakültesi, Tarla Bitkileri Bölümü, Ankara \\ Sorumlu yazar e-posta: (Corresponding author e-mail) C.Yasar.Ciftci@agri.ankara.edu.tr
}

\section{Öz}

1847 yılında İstanbul Ayamama'da "Ziraat Talimhanesi” adı ile başlayan tarımsal yükseköğretim, Halkal Ziraat Mekteb-i Ali'si, Ankara Yüksek Ziraat Mekteb-i, Yüksek Ziraat Enstitüsü Ziraat Fakültesi, Ankara Üniversitesi Ziraat Fakültesi olarak devam etmiştir. 1955 yılında Ege Üniversitesi Ziraat Fakültesi, 1957 yılında Atatürk Üniversitesi Ziraat Fakültesi ve değişik isimlerle sayıları bugün 39'a (1'i vakıf üniversitesi) ulaşmıştır. Ayrıca, 2012-2013 eğitim öğretim yılında 2 yıllık meslek yüksekokullarında 376 normal, 73 ikinci öğretim olmak üzere 449 tarımsal yükseköğretimle ilgili program öğrenci talep etmiştir. Tarla Bitkileri Bölümü, 30.10.1933 tarihinde açılan Yüksek Ziraat Enstitüsü Ziraat Fakültesinde Nebatat Yetiştirme ve Nebatat Islahı Enstitüsü adını almış ve günümüze kadar değişik isimler altında öğretimi sürdürmüştür. Günümüzde Tarla Bitkileri Bölümü olarak öğretimi sürdürmektedir. Bugün ülkemizde 109 devlet, 76 vakıf üniversitesi olmak üzere toplam 185 üniversite bulunmaktadır. Devlet üniversitesi sayısı 1933-1960 yılları arasında 7 iken, 1961-1980 yıllarında açılanlarla 19'a, 1981-2005 yılları arasında açılanlarla da 53'e çıkmıştır. 2006-2015 yılları arasındaki 9 yıl gibi kısa bir dönemde açılan 56 üniversite ile birlikte sayı 109'a ulaşmıştır. Bu bildiride, 1970 sonlarına kadar sınavlarda \%1-10 aralığına giren öğrencilerin tercih ettiği Ziraat Fakültelerinin bugün geldiği durum ile sorunlar ve çözüm önerileri açıklanmaya çalışılmıştır.

Anahtar Kelimeler: Ziraat Fakülteleri tarihi, durum, sorun, çözüm

\section{Current Status of Agricultural Higher Education and Field Crops Department in Turkey}

\begin{abstract}
Turkey's first agricultural higher education started with named "Ziraat Talimhanesi" in 1847, İstanbul Ayamama; which is followed by several other schools: Halkalı Agriculture Grand School, Ankara High Agriculture School and Agricultural Faculty of High Agriculture Institute (present Ankara University Faculty of Agriculture). Today, number of Turkish universities offering degrees on agriculture in different disciplines are reached 39 (one being foundation university) which was inititated with the faculties of agriculture of Ege University (1955) and Ataturk University (1957). In addition to the university and collage education, 449 (376 first and 73 second teaching) undergraduate agricultural programs in vocational schools accepted admissions for 2012-2013 academic year. Field Crops Departments in Turkey were originated from Plant Cultivation and Plant Breeding Institute (under Agricultural Faculty of High Agriculture Institute) which undergo many title changes from its founding in 30.10.1933 until today. Currently, there are 185 universities (109 state and 76 foundation) in Turkey. There were only 7 state universities between 1933-1960 when total number of universities rapidly increased and reached 19 by 1980 and 53 by 2005 . In a duration of 9 years between 2006 and 2015, 56 additional universities are founded and total number of Turkish universities are increased to 109. This paper aims to explain current status and evaluate solutions for problems concerning faculties of agriculture in Turkey which used to accept top \%1-10 students in university admission exams until late 1970's.
\end{abstract}

Keywords: History of Faculties of Agriculture, current status, problems, solutions

\section{Giriş}

848 yılında İstanbul Ayamama'da "Ziraat Talimhanesi" adı ile başlayan tarımsal yükseköğretim, Halkalı Ziraat Mekteb-i Ali'si, Ankara Yüksek Ziraat Mekteb-i, Yüksek Ziraat Enstitüsü Ziraat Fakültesi, Ankara Üniversitesi
Ziraat Fakültesi olarak devam etmiş, 1955 yılında Ege Üniversitesi Ziraat Fakültesi, 1957 yılında Atatürk Üniversitesi Ziraat Fakültesi ve değişik isimlerle sayıları bugün 39'a (1'i vakıf üniversitesi) ulaşmıştır. 
Ayrıca, 2012 - 2013 eğitim öğretim yılında 2 yıllık meslek yüksekokullarında 376 normal, 73 ikinci öğretim olmak üzere 449 tarımsal yükseköğretimle ilgili program öğrenci talep etmiştir.

Tarla Bitkileri Bölümü, 30.10.1933 tarihinde açılan Yüksek Ziraat Enstitüsü Ziraat Fakültesi'nde Nebatat Yetiştirme ve Nebatat Islahı Enstitüsü adını almış ve günümüze kadar değişik isimler altında öğretimi sürdürmüştür. Günümüzde Tarla Bitkileri Bölümü olarak öğretimi sürdürmektedir.

Bugün ülkemizde 109 devlet, 76 vakıf üniversitesi olmak üzere toplam 185 üniversite bulunmaktadır. Devlet üniversite sayısı 19331960 yılları arasında 7 iken, 1961-1980 yıllarında açılanlarla 19'a, 1981-2005 yılları arasında açılanlarla 53'e çıkmıştır. 2006-2015 yılları arasındaki kısa bir dönemde açılan 56 üniversite ile birlikte sayı 109'a ulaşmıştır.

Bu bildiride, 1970 sonlarına kadar sınavlarda \%1-10 aralığına giren öğrencilerin tercih ettiği ziraat fakültelerinin bugün geldiği durum ile sorunlar ve çözüm önerileri açıklanmaya çalışılacaktır.

\section{Tarımsal Yükseköğretimle İlgili Fakülteler ve Yüksekokullar}

Tarımsal yükseköğretimle ilgili 6 farklı isimle, 39 fakülte ve 2 yüksekokul (dört yıllık) olarak toplam 41yükseköğretim kurumu bulunmaktadır. Bu kurumlar çizelge 1de gösterilmiştir.

Ayrıca, 2012 - 2013 eğitim öğretim yılında 2 yıllık meslek yüksekokullarında 376 normal, 73 ikinci öğretim olmak üzere 449 tarımsal yükseköğretimle ilgili program öğrenci talep etmiştir (Çiftçi ve Benlioğlu 2014). Açık Öğretim Fakültesi tarım programı hariç, 2012 yılında tarımla ilgili programların kontenjanı 17155 'dir. İlk tercih döneminde bu programlarda açık kalan kontenjan 6971 olup, diğer bir ifade ile kontenjanın \%59.4'ü dolmuş, \%40,6'sı boş kalmıştır. Hal böyle iken, yeni program açmanın, ikinci öğretim program açmanın amacı nedir? (Çiftçi ve Benlioğlu 2014).

\section{Ziraat Fakülteleri}

Ülkemizde ziraat fakültesi adıyla 29 fakülte bulunmaktadır. $\mathrm{Bu}$ fakültelerde bulunan bölümler, kontenjanlar ve ilk tercih döneminde açık kalan kontenjanlar Çizelge 2'de verilmiştir.

Çizelge 1. Tarımsal yükseköğretimle ilgili fakülte ve yüksekokullar

Table 1. Faculties and vocational schools for agriculturel higher education

\begin{tabular}{lccc}
\hline & Devlet & Vakıf & Toplam \\
\hline Üniversite & 109 & 76 & 185 \\
Ziraat Fakültesi & 29 & - & \\
Ziraat ve Doğa Bilimleri Fakültesi & 6 & - & \\
Tarım Bilimleri ve Teknolojileri Fakültesi & 2 & - & \\
Tarım Bilimleri Fakültesi & 1 & - & \\
Tarım ve Doğa Bilimleri Fakültesi & - & 1 & 41 \\
Hayvansal Üretim Yüksekokulu (4 yıllık) & 2 & - & \\
TOPLAM & 40 & 1 & 4 \\
\hline
\end{tabular}

Çizelge 2. Ziraat Fakültelerinde bulunan bölümler, kontenjanlar ve ilk tercih döneminde açık kalan kontenjanlar (Çiftçi 2013; Anonim 2014; Anonim 2015)

Table 2. Departments, announced and unfilled quotas of faculties of agriculture (Çiftçi 2013; Anonim 2014; Anonim 2015)

\begin{tabular}{|c|c|c|c|c|c|c|c|c|c|}
\hline \multicolumn{10}{|c|}{ Adnan Menderes Üniversitesi Ziraat Fakültesi (Aydın) } \\
\hline & & \multicolumn{4}{|c|}{ Kontenjanlar } & \multicolumn{4}{|c|}{ İlk Tercihte Açık Kontenjanlar } \\
\hline & Bölümler & 2012 & 2013 & 2014 & 2015 & 2012 & 2013 & 2014 & 2015 \\
\hline 1 & Bahçe Bitkileri & 36 & 36 & 36 & 41 & 0 & 2 & 2 & 2 \\
\hline 2 & Bitki Koruma & 36 & 36 & 36 & 41 & 0 & 0 & 3 & 2 \\
\hline 3 & Biyosistem Mühendisliği* & - & $41^{*}$ & $52+1$ & $52+1$ & - & 4 & $5+1$ & $2+1$ \\
\hline 4 & Peyzaj Mimarlığı & 36 & 36 & 36 & 41 & 1 & 2 & 3 & 3 \\
\hline 5 & Su Ürünleri Mühendisliği & 47 & 26 & 11 & $0^{* * *}$ & 45 & 25 & 11 & $0 * * *$ \\
\hline 6 & Süt Teknolojisi & $47^{* *}$ & 31 & $21+1$ & $0 * * *$ & $47^{* *}$ & 28 & $19+1$ & $0 * * *$ \\
\hline 7 & Tarım Ekonomisi & 36 & 36 & 36 & 41 & 1 & 2 & 2 & 2 \\
\hline 8 & Tarımsal Biyoteknoloji* & - & $41^{*}$ & $41+1$ & 41 & - & 1 & $13+1$ & 1 \\
\hline 9 & Tarla Bitkileri & 36 & 36 & $36+1$ & $41+1$ & 1 & 3 & 1 & $2+1$ \\
\hline 10 & Toprak Bilimi ve Bitki Besleme & 36 & 36 & 36 & 31 & 2 & 4 & 22 & 9 \\
\hline 11 & Zootekni & 36 & 31 & $21+1$ & 21 & 22 & 13 & $7+1$ & 0 \\
\hline & Bölüm sayısı & & & & $11-2$ & & & & \\
\hline & TOPLAM & 346 & 386 & 367 & 352 & 180 & 84 & 92 & 25 \\
\hline
\end{tabular}

${ }^{*}$ ) Bu yıl öğrenci talebi, ${ }^{* *}$ )Ek yerleştirmede talep edildi , ${ }^{* * *}$ )YÖK çe kontenjan verilmedi.

$\left.{ }^{*}\right)$ Student demand for this year ${ }^{* *}$ ) Additional quota was requested, ${ }^{* *}$ ) Quota of student was not given by YOK. 
Çizelge 2. (Devamı)

Table 2. (Continued)

\begin{tabular}{|c|c|c|c|c|c|c|c|c|c|}
\hline \multicolumn{10}{|c|}{ Ahi Evran Üniversitesi Ziraat Fakültesi (Kırşehir) } \\
\hline & \multirow[b]{2}{*}{ Bölümler } & \multicolumn{2}{|c|}{ Kontenjanlar } & \multirow[b]{2}{*}{2014} & \multirow[b]{2}{*}{2015} & \multicolumn{4}{|c|}{ İlk Tercihte Açık Kontenjanlar } \\
\hline & & 2012 & 2013 & & & 2012 & 2013 & 2014 & 2015 \\
\hline 1 & Bahçe Bitkileri & 36 & 36 & 36 & $0^{* * *}$ & 16 & 5 & 33 & $0^{\star \star \star}$ \\
\hline 2 & Bitki Koruma & - & - & - & $41^{*}$ & - & - & - & 1 \\
\hline 3 & Biyosistem Mühendisliği & - & - & - & - & - & - & - & - \\
\hline 4 & Peyzaj Mimarlığı & - & - & - & - & _ & - & - & - \\
\hline 5 & Tarım Ekonomisi & - & - & - & - & - & - & - & - \\
\hline 6 & Tarımsal Biyoteknoloji & 47 & 47 & 47 & 36 & 31 & 3 & 37 & 19 \\
\hline 7 & Tarla Bitkileri & 36 & 36 & 36 & 36 & 17 & 0 & 14 & 11 \\
\hline 8 & Toprak Bilimi ve Bitki Besl. & - & - & - & - & - & - & - & - \\
\hline \multirow[t]{3}{*}{9} & Zootekni* & - & $31^{*}$ & 21 & $0^{* * *}$ & - & $29^{*}$ & 18 & $0^{\star * *}$ \\
\hline & Bölüm sayısı & & & & $9-6$ & & & & \\
\hline & TOPLAM & 119 & 150 & 140 & 113 & 64 & 37 & 102 & \\
\hline
\end{tabular}

\begin{tabular}{|c|c|c|c|c|c|c|c|c|c|}
\hline \multicolumn{10}{|c|}{ Akdeniz Üniversitesi Ziraat Fakültesi (Antalya) } \\
\hline & \multirow{2}{*}{ 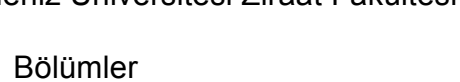 } & \multicolumn{4}{|c|}{ Kontenjanlar } & \multicolumn{4}{|c|}{ İlk Tercihte Açık Kontenjanlar } \\
\hline & & 2012 & 2013 & 2014 & 2015 & 2012 & 2013 & 2014 & 2015 \\
\hline 1 & Bahçe Bitkileri & 36 & 36 & $36+1$ & 36 & 2 & 1 & $0+1$ & 0 \\
\hline 2 & Bitki Koruma & 36 & 36 & 36 & 36 & 0 & 1 & 0 & 1 \\
\hline 3 & Peyzaj Mimarlığı & 36 & 36 & 36 & 36 & 1 & 2 & 0 & 1 \\
\hline \multirow[t]{2}{*}{4} & Tarım Ekonomisi & 36 & 36 & 36 & 36 & 2 & 1 & 0 & \multirow[t]{2}{*}{3} \\
\hline & Tarım Makineleri & 36 & 31 & 21 & - & 25 & 24 & 8 & \\
\hline 5 & Tar. Mak. ve Tekno.Müh. & - & - & - & 21 & - & - & - & 1 \\
\hline 6 & Tarımsal Yapılar ve Sulama & 36 & 36 & 21 & $0^{* * *}$ & 15 & 29 & 13 & $0^{* * *}$ \\
\hline 7 & Tarla Bitkileri & 36 & 36 & 36 & 36 & 1 & 1 & 1 & 2 \\
\hline 8 & Toprak Bilimi ve Bitki Besl. & 36 & 36 & 31 & 31 & 0 & 1 & 0 & 0 \\
\hline \multirow[t]{3}{*}{9} & Zootekni & 36 & \multirow[t]{2}{*}{36} & \multirow[t]{2}{*}{31} & 31 & \multirow[t]{2}{*}{0} & \multirow[t]{2}{*}{4} & \multirow[t]{2}{*}{6} & \multirow[t]{2}{*}{1} \\
\hline & Bölüm sayısı & & & & $9-1$ & & & & \\
\hline & TOPLAM & 324 & 319 & 285 & 263 & 46 & 84 & 29 & 9 \\
\hline \multicolumn{6}{|c|}{ Ankara Üniversitesi Ziraat Fakültesi } & \multirow{2}{*}{\multicolumn{4}{|c|}{ Ilk Tercihte Aclk Kontenianlar }} \\
\hline & & & Kont & enjanlar & & & & & \\
\hline & Bölümler & 2012 & 2013 & 2014 & 2015 & 2012 & 2013 & 2014 & 2015 \\
\hline 1 & Bahçe Bitkileri & 47 & 47 & $47+1$ & $47+1$ & 0 & 4 & 3 & $2+1$ \\
\hline 2 & Bitki Koruma & 47 & 47 & 47 & 47 & 3 & 1 & 1 & 5 \\
\hline \multirow[t]{2}{*}{3} & Peyzaj Mimarlığı & 67 & 67 & 67 & 67 & 6 & 3 & 2 & 4 \\
\hline & Su Ürünleri Mühendisliği & 47 & 41 & 26 & 26 & 27 & 31 & 11 & 0 \\
\hline 4 & Su Ürünleri Müh. (İngilizce)* & - & - & $21^{*}$ & 21 & - & - & 14 & 0 \\
\hline 5 & Süt Teknolojisi & 47 & 47 & 21 & $21+1$ & 24 & 30 & 12 & $1+1$ \\
\hline \multirow[t]{2}{*}{6} & Tarım Ekonomisi & 47 & 47 & 47 & 47 & 0 & 3 & 5 & \multirow[t]{2}{*}{2} \\
\hline & Tarım Makineleri & 47 & 41 & 41 & - & 22 & 23 & 23 & \\
\hline 7 & Tar.Mak. ve Tek. Mühendisliği & - & - & - & 41 & & & & 3 \\
\hline 8 & Tarımsal Yapılar ve Sulama & 47 & 47 & $31+1$ & 31 & 1 & 8 & $10+1$ & 13 \\
\hline 9 & Tarla Bitkileri & 47 & 47 & 47 & $47+1$ & 1 & 1 & 5 & $0+1$ \\
\hline 10 & Toprak Bilimi ve Bitki Besl. & 47 & 47 & 41 & $41+1$ & 1 & 0 & 5 & $2+1$ \\
\hline \multirow[t]{3}{*}{11} & Zootekni & 47 & 47 & 41 & 41 & 1 & 1 & 1 & 2 \\
\hline & Bölüm sayısı & & & & 11 & & & & \\
\hline & TOPLAM & 537 & 525 & 479 & 487 & 86 & 105 & 93 & 38 \\
\hline \multicolumn{10}{|c|}{ Atatürk Üniversitesi Ziraat Fakültesi (Erzurum) } \\
\hline & & \multicolumn{4}{|c|}{ Kontenianlar } & \multicolumn{4}{|c|}{ İlk Tercihte Açık Kontenjanlar } \\
\hline & Bölümler & 2012 & 2013 & 2014 & 2015 & 2012 & 2013 & 2014 & 2015 \\
\hline 1 & Bahçe Bitkileri & 36 & 36 & 36 & $0^{\star \star *}$ & 1 & 0 & 27 & $0^{* * *}$ \\
\hline 2 & Bitki Koruma & 36 & 36 & 36 & 36 & 0 & 1 & 0 & 4 \\
\hline & Gıda Mühendisliği & 77 & 77 & 77 & 77 & 1 & 2 & 2 & 4 \\
\hline 3 & Gıda Mühendisliği İ.Ö. & 77 & 77 & 77 & 77 & 2 & 4 & 6 & 7 \\
\hline 4 & Tarım Ekonomisi & 36 & 36 & 36 & 36 & 2 & 1 & 3 & 1 \\
\hline & Tarım Makineleri & 36 & 21 & 21 & - & 32 & 20 & 21 & \\
\hline 5 & Tar.Mak. ve Tek. Mühendisliği & - & - & - & 21 & - & - & - & 19 \\
\hline 6 & Tarımsal Biyoteknoloji & 36 & 36 & $36+1$ & $0^{* * *}$ & 17 & 0 & $31+1$ & $0^{* * *}$ \\
\hline 7 & Tarımsal Yapılar ve Sulama & 36 & $0^{* * *}$ & $0^{* * *}$ & $0^{* * *}$ & 36 & $0^{* * *}$ & $0^{* * *}$ & $0^{* * *}$ \\
\hline
\end{tabular}

$\left.{ }^{*}\right)$ Bu yıl öğrenci talebi, $\left.{ }^{* *}\right)$ Ek yerleştirmede talep edildi , $\left.{ }^{* * *}\right)$ YÖK çe kontenjan verilmedi.

*) Student demand for this year ${ }^{* *}$ ) Additional quota was requested, ${ }^{* *}$ ) Quota of student was not given by YOK. 
Çizelge 2. (Devamı)

Table 2. (Continued)

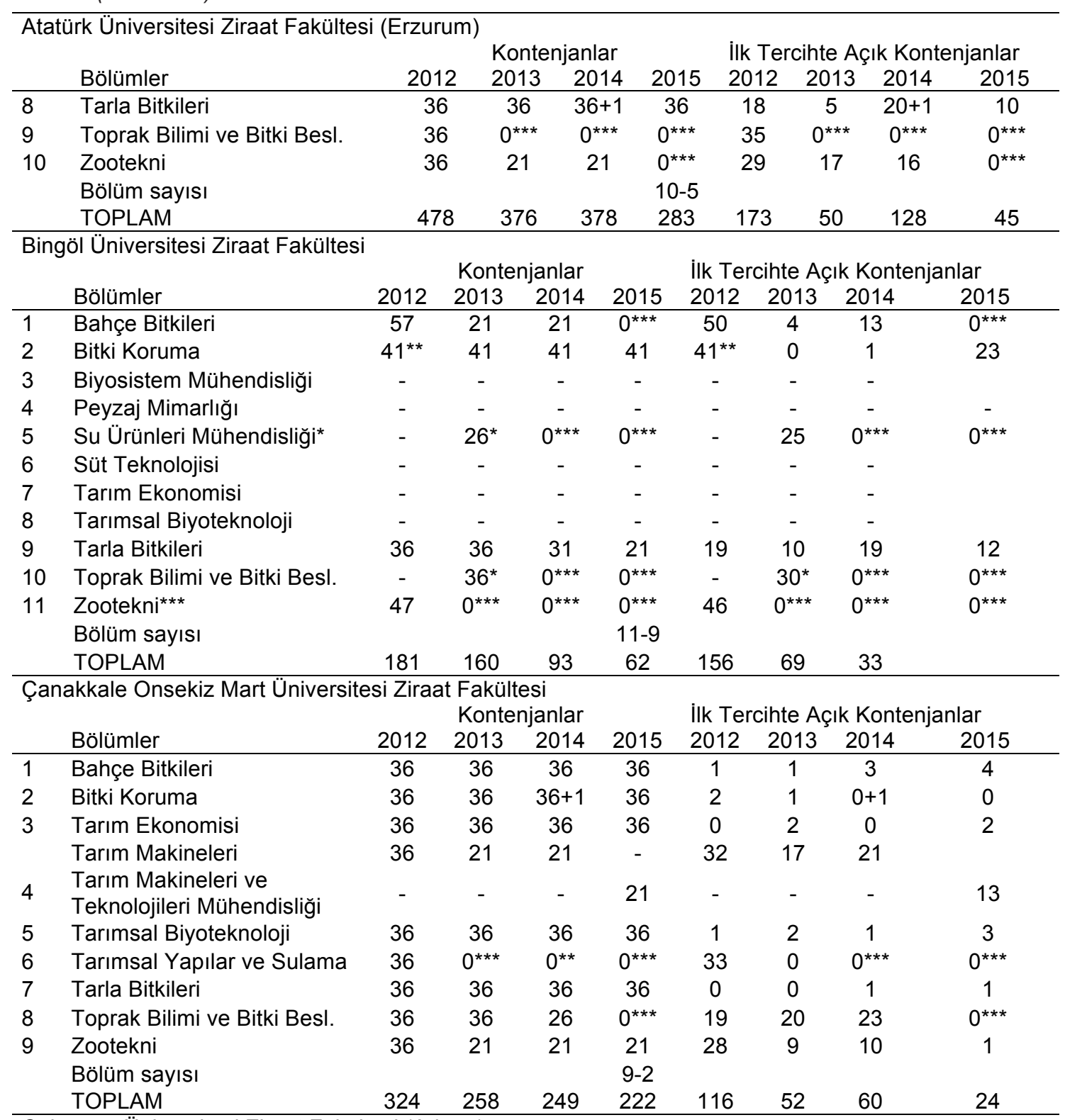

Çukurova Üniversitesi Ziraat Fakültesi (Adana)

Kontenjanlar IIlk Tercihte Açık Kontenjanlar

\begin{tabular}{llcccccccc} 
& Bölümler & 2012 & 2013 & 2014 & 2015 & 2012 & 2013 & 2014 & 2015 \\
\hline 1 & Bahçe Bitkileri & 47 & 47 & 47 & 47 & 2 & 2 & 0 & 1 \\
2 & Bitki Koruma & 47 & 47 & $47+1$ & $47+1$ & 4 & 1 & $0+1$ & $3+1$ \\
3 & Gıda Mühendisliği & 77 & 77 & 77 & 77 & 1 & 0 & 1 & 1 \\
4 & Peyzaj Mimarlığı & 57 & 57 & 57 & 57 & 1 & 5 & 2 & 7 \\
5 & Tarım Ekonomisi & 47 & 47 & 47 & 47 & 1 & 0 & 1 & 1 \\
6 & Tarım Makineleri & 47 & 31 & 21 & - & 40 & 24 & 18 & \\
7 & Tarım Mak. ve Tek. Mühen. & - & - & - & 21 & - & - & - & 7 \\
8 & Tarımsal Yapılar ve Sulama & 47 & 47 & $21+1$ & $0^{* * *}$ & 22 & 33 & $14+1$ & $0^{* * *}$ \\
9 & Tarla Bitkileri & 47 & 47 & 47 & 47 & 1 & 0 & 1 & 4 \\
10 & Toprak Bilimi ve Bitki Besl. & 47 & 47 & 41 & 41 & 0 & 0 & 2 & 0 \\
& Zootekni & 47 & 47 & 41 & 31 & 14 & 16 & 24 & 0 \\
& Bölüm sayısı & & & & $10-1$ & & & & \\
& TOPLAM & 510 & 494 & 448 & 416 & 86 & 81 & 65 & 24 \\
\hline
\end{tabular}

*) Bu yıl öğrenci talebi, ${ }^{* *}$ )Ek yerleştirmede talep edildi , $\left.{ }^{* * *}\right)$ YÖK çe kontenjan verilmedi.

*) Student demand for this year ${ }^{* *}$ ) Additional quota was requested, $\left.{ }^{* *}\right)$ Quota of student was not given by YOK. 
Çizelge 2. (Devamı)

Table 2. (Continued)

\begin{tabular}{|c|c|c|c|c|c|c|c|c|c|}
\hline \multicolumn{10}{|c|}{ Dicle Üniversitesi Ziraat Fakültesi (Diyarbakır) } \\
\hline & \multirow[b]{2}{*}{ Bölümler } & \multicolumn{4}{|c|}{ Kontenjanlar } & \multicolumn{4}{|c|}{ İlk Tercihte Açık Kontenjanlar } \\
\hline & & 2012 & 2013 & 2014 & 2015 & 2012 & 2013 & 2014 & 20 \\
\hline 1 & Bahçe Bitkileri & 36 & 36 & 36 & 36 & 0 & 2 & 2 & 0 \\
\hline 2 & Bitki Koruma & 36 & 36 & 36 & 36 & 0 & 2 & 0 & 0 \\
\hline 3 & Tarım Ekonomisi & - & - & - & - & - & - & - & - \\
\hline 4 & Tarım Makineleri & - & - & - & - & - & - & - & - \\
\hline 5 & Tarımsal Yapılar ve Sulama & - & - & - & - & - & - & - & - \\
\hline 6 & Tarla Bitkileri & 36 & 36 & 36 & 36 & 0 & 0 & 3 & 0 \\
\hline 7 & Toprak Bilimi ve Bitki Besl. & - & - & - & - & - & - & - & - \\
\hline \multirow[t]{3}{*}{8} & Zootekni & 36 & 36 & 31 & 31 & 0 & 1 & 1 & 4 \\
\hline & Bölüm sayısı & & & & $8-4$ & & & & \\
\hline & TOPLAM & 144 & 144 & 139 & 139 & 0 & 5 & 6 & 4 \\
\hline \multicolumn{10}{|c|}{ Ege Üniversitesi Ziraat Fakültesi (İzmir) } \\
\hline & & \multicolumn{4}{|c|}{ Kontenjanlar } & \multicolumn{4}{|c|}{ İlk Tercihte Açık Kontenjanlar } \\
\hline & Bölümler & 2012 & 2013 & 2014 & 2015 & 2012 & 2013 & 2014 & 20 \\
\hline 1 & Bahçe Bitkileri & 36 & 36 & 36 & 36 & 1 & 1 & 3 & 0 \\
\hline 2 & Bitki Koruma & 36 & 36 & 36 & $36+1$ & 1 & 1 & 2 & $1+$ \\
\hline 3 & Peyzaj Mimarlığı & 67 & 67 & 67 & $67+1$ & 0 & 0 & 2 & $4+$ \\
\hline 4 & Süt Teknolojisi & 36 & 36 & 21 & $21+1$ & 10 & 19 & 9 & $1+$ \\
\hline 5 & Tarım Ekonomisi & 36 & 36 & 36 & 36 & 1 & 1 & 1 & 0 \\
\hline \multirow[t]{2}{*}{6} & Tarım Makineleri & 36 & 31 & 31 & - & 1 & 3 & 1 & \\
\hline & Tarım Mak. ve Tekn. Müh. & - & - & - & 31 & - & - & - & 2 \\
\hline 7 & Tarımsal Yapılar ve Sulama & 36 & 36 & 31 & $31+1$ & 1 & 1 & 15 & 20 \\
\hline 8 & Tarla Bitkileri & 36 & 36 & 36 & 36 & 1 & 1 & 0 & 0 \\
\hline 9 & Toprak Bilimi ve Bitki Besl. & 36 & 36 & 31 & 31 & 1 & 0 & 4 & 1 \\
\hline \multirow[t]{3}{*}{10} & Zootekni & 36 & 36 & 31 & 31 & 1 & 1 & 1 & 1 \\
\hline & Bölüm sayısı & & & & 10 & & & & \\
\hline & TOPLAM & 391 & 386 & 356 & 360 & 18 & 28 & 38 & 3 \\
\hline \multicolumn{10}{|c|}{ Erciyes Üniversitesi Ziraat Fakültesi (Kayseri) } \\
\hline & & \multicolumn{4}{|c|}{ Kontenjanlar } & \multicolumn{4}{|c|}{ İlk Tercihte Açık Kontenjanlar } \\
\hline & Bölümler & 2012 & 2013 & 2014 & 2015 & 2012 & 2013 & 2014 & 201 \\
\hline 1 & Bahçe Bitkileri & 36 & 36 & 36 & 36 & 1 & 1 & 4 & 5 \\
\hline 2 & Bitki Koruma & 36 & 36 & 36 & 36 & 2 & 3 & 1 & 0 \\
\hline 3 & Biyosistem Mühendisliği & 36 & 36 & $36+1$ & 26 & 3 & 8 & $26+1$ & 10 \\
\hline 4 & Tarımsal Biyoteknoloji & 36 & 36 & 36 & 26 & 5 & 0 & 22 & 0 \\
\hline 5 & Tarla Bitkileri & 36 & 36 & 36 & 37 & 0 & 1 & 1 & 3 \\
\hline 6 & Toprak Bilimi ve Bitki Besl. & - & - & - & - & - & - & - & - \\
\hline \multirow[t]{3}{*}{7} & Zootekni & 36 & 31 & 21 & $0^{* * *}$ & 24 & 25 & 15 & $0 *$ \\
\hline & Bölüm sayısı & & & & $7-2$ & & & & \\
\hline & TOPLAM & 216 & 211 & 202 & 161 & 35 & 38 & 70 & 18 \\
\hline
\end{tabular}

Eskişehir Osmangazi Üniversitesi Ziraat Fakültesi

Bölümler

Kontenjanlar İlk Tercihte Açık Kontenjanlar

\begin{tabular}{llcccccccr} 
& Bölümler & 2012 & 2013 & 2014 & 2015 & 2012 & 2013 & 2014 & 201 \\
\hline 1 & Bahçe Bitkileri & 36 & 36 & 36 & 36 & 2 & 2 & 3 & 1 \\
2 & Bitki Koruma & - & - & - & - & - & - & - & - \\
3 & Biyosistem Mühendisliği & - & - & - & - & - & - & - & - \\
4 & Gıda Mühendisliği & - & - & - & - & - & - & - & - \\
5 & Peyzaj Mimarlığı & - & - & - & - & - & - & - & - \\
6 & Tarım Ekonomisi & - & - & - & - & - & - & - & - \\
7 & Tarımsal Biyoteknoloji** & $41^{* *}$ & 41 & 41 & 41 & $41^{* *}$ & 1 & 1 & 2 \\
8 & Tarla Bitkileri & 36 & 36 & 36 & 36 & 1 & 1 & 0 & 0 \\
9 & Toprak Bilimi ve Bitki Besl. & - & - & - & - & - & - & - & - \\
10 & Zootekni & 36 & 36 & 31 & 31 & 9 & 3 & 9 & 1 \\
& Bölüm sayısı & & & & $10-6$ & & & & \\
& TOPLAM & 149 & 149 & 144 & 144 & 53 & 7 & 13 & 4 \\
\hline
\end{tabular}

*) Bu yıl öğrenci talebi, ${ }^{* *}$ )Ek yerleştirmede talep edildi , $\left.{ }^{* * *}\right)$ YÖK çe kontenjan verilmedi.

*) Student demand for this year ${ }^{* *}$ ) Additional quota was requested, ${ }^{* * *}$ ) Quota of student was not given by YOK. 
Çizelge 2. (Devamı)

Table 2. (Continued)

\begin{tabular}{llcccccccc}
\hline Gaziosmanpaşa Üniversitesi Ziraat Fakültesi (Tokat) & \multicolumn{4}{c}{ Kontenjanlar } & \multicolumn{3}{c}{ Ilk Tercihte Açık Kontenjanlar } \\
& Bölümler & 2012 & 2013 & 2014 & 2015 & 2012 & 2013 & 2014 & 201 \\
\hline 1 & Bahçe Bitkileri & 36 & 36 & 36 & 26 & 7 & 7 & 21 & 14 \\
2 & Bitki Koruma & 36 & 36 & 36 & 36 & 0 & 1 & 2 & 2 \\
3 & Biyosistem Mühendisliği & 36 & 36 & 36 & $0^{* * *}$ & 2 & 28 & 32 & $0^{* *}$ \\
4 & Su Ürünleri Mühendisliği & 47 & 26 & $0^{* * *}$ & $0^{* * *}$ & 44 & 26 & $0^{* * *}$ & $0^{* *}$ \\
5 & Tarım Ekonomisi & 36 & 36 & 36 & 36 & 2 & 1 & 1 & 0 \\
6 & Tarla Bitkileri & 36 & 36 & 36 & 26 & 17 & 0 & 18 & 13 \\
7 & Toprak Bilimi ve Bitki Besl. & 36 & 21 & 21 & $0^{* * *}$ & 32 & 19 & 17 & $0^{* *}$ \\
8 & Zootekni & - & - & - & - & - & - & - & - \\
& Bölüm sayısı & & & & $8-3$ & & & & 29 \\
& TOPLAM & 263 & 227 & 201 & 134 & 104 & 82 & 91 & 29 \\
\hline
\end{tabular}

Harran Üniversitesi Ziraat Fakültesi (Şanlıurfa)

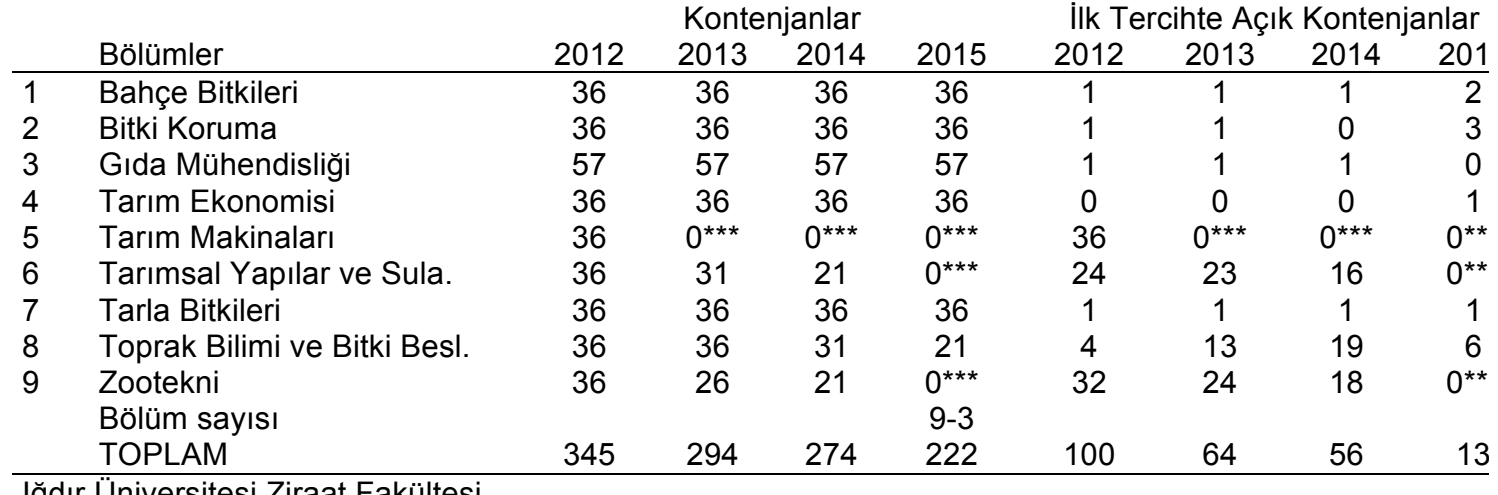

Iğdır Üniversitesi Ziraat Fakültesi

Bölümler Kontenjanlar İlk Tercihte Açık Kontenjanlar

\begin{tabular}{llcccccccc} 
& Bölümler & 2012 & 2013 & 2014 & 2015 & 2012 & 2013 & 2014 & 201 \\
\hline 1 & Bahçe Bitkileri & 36 & 21 & 11 & $0^{* * *}$ & 34 & 17 & 6 & $0^{* *}$ \\
2 & Bitki Koruma & 36 & 36 & 41 & 26 & 4 & 0 & 23 & 17 \\
3 & Biyosistem Mühendisliği* & - & $31^{*}$ & 11 & $0^{* * *}$ & - & 30 & 11 & $0^{* *}$ \\
4 & Peyzaj Mimarlığı & - & - & - & - & - & - & - & - \\
5 & Tarım Ekonomisi & 36 & 36 & 36 & 36 & 3 & 6 & 2 & 4 \\
6 & Tarla Bitkileri & 36 & 36 & 11 & $0^{* * *}$ & 34 & 33 & 6 & $0^{* *}$ \\
7 & Toprak Bilimi ve Bitki Besı. & - & - & - & - & - & - & - & - \\
8 & Zootekni & - & - & - & - & - & - & - & - \\
& Bölüm sayısı & & & & $8-6$ & & & & \\
& TOPLAM & 144 & 160 & 110 & 62 & 75 & 86 & 48 &
\end{tabular}

İnönü Üniversitesi Ziraat Fakültesi (Malatya)

\begin{tabular}{llcccccccr} 
& & \multicolumn{4}{c}{ Kontenjanlar } & \multicolumn{4}{c}{ İlk Tercihte Açık Kontenjanlar } \\
& Bölümler & 2012 & 2013 & 2014 & 2015 & 2012 & 2013 & 2014 & 201 \\
\hline 1 & Bahçe Bitkileri & 36 & 47 & 47 & 47 & 1 & 4 & 0 & 5 \\
2 & $\begin{array}{l}\text { Bitki Koruma* } \\
\text { Bölüm sayısı }\end{array}$ & - & - & $31^{*}$ & 31 & - & - & 1 & 2 \\
& TOPLAM & 36 & 47 & 78 & 78 & 1 & 4 & 1 & 7 \\
\hline
\end{tabular}

Kahramanmaraş Sütçü İmam Üniversitesi Ziraat Fakültesi

\begin{tabular}{llcccccccc} 
& & \multicolumn{3}{c}{ Kontenjanlar } & \multicolumn{4}{c}{ İlk Tercihte Açık Kontenjanlar } \\
& Bölümler & 2012 & 2013 & 2014 & 2015 & 2012 & 2013 & 2014 & 201 \\
\hline 1 & Bahçe Bitkileri & 36 & 36 & 36 & 36 & 0 & 0 & 2 & 12 \\
2 & Bitki Koruma & 36 & 36 & 36 & 36 & 2 & 2 & 0 & 2 \\
3 & Biyosistem Mühendisliği & 36 & 36 & 36 & $0^{* * *}$ & 6 & 23 & 35 & $0^{* *}$ \\
4 & Gıda Mühendisliği & 47 & 47 & 47 & $0^{* * *}$ & 1 & 2 & 2 & $0^{* *}$ \\
5 & Tarım Ekonomisi & 36 & 36 & 36 & 36 & 1 & 2 & 3 & 3 \\
6 & Tarla Bitkileri & 36 & 36 & 36 & 36 & 2 & 3 & 2 & 1 \\
7 & Toprak Bilimi ve Bitki Besle. & 36 & 31 & 21 & $0^{* * *}$ & 27 & 23 & 21 & $0^{* *}$ \\
8 & Zootekni & 36 & 31 & 21 & $0^{* * *}$ & 28 & 22 & 15 & $0^{* *}$ \\
& Bölüm sayısı & & & & $8-4$ & & & & \\
& TOPLAM & 299 & 289 & 269 & 144 & 67 & 77 & 80 & 18 \\
\hline
\end{tabular}

*) Bu yıl öğrenci talebi, ${ }^{* *}$ )Ek yerleştirmede talep edildi , ${ }^{* * *}$ )YÖK çe kontenjan verilmedi.

$\left.{ }^{*}\right)$ Student demand for this year ${ }^{* *}$ ) Additional quota was requested, ${ }^{* *}$ ) Quota of student was not given by YOK. 
Çizelge 2. (Devamı)

Table 2. (Continued)

\begin{tabular}{|c|c|c|c|c|c|c|c|c|c|}
\hline \multicolumn{10}{|c|}{ Kilis 7 Aralık Üniversitesi Ziraat Fakültesi } \\
\hline & \multirow[b]{2}{*}{ Bölümler } & \multicolumn{4}{|c|}{ Kontenjanlar } & \multicolumn{4}{|c|}{ İlk Tercihte Açık Kontenjanlar } \\
\hline & & 2012 & 2013 & 2014 & 2015 & 2012 & 2013 & 2014 & 201 \\
\hline 1 & Bahçe Bitkileri & & & & & & & & \\
\hline 2 & Zootekni & & & & & & & & \\
\hline & Bölüm Sayısı & & & & $2-2$ & & & & \\
\hline
\end{tabular}

Mustafa Kemal Üniversitesi Ziraat Fakültesi (Hatay)

\begin{tabular}{|c|c|c|c|c|c|c|c|c|c|}
\hline & \multirow[b]{2}{*}{ Bölümler } & \multicolumn{4}{|c|}{ Kontenjanlar } & \multicolumn{4}{|c|}{ İlk Tercihte Açık Kontenjanlar } \\
\hline & & 2012 & 2013 & 2014 & 2015 & 2012 & 2013 & 2014 & 201 \\
\hline 1 & Bahçe Bitkileri & 36 & 36 & 36 & 36 & 0 & 0 & 1 & 5 \\
\hline 2 & Bitki Koruma & 36 & 36 & 36 & 36 & 1 & 0 & 0 & 0 \\
\hline 3 & Biyosistem Mühendisliği & 36 & 36 & 36 & $0^{* * *}$ & 2 & 23 & 29 & 0 ** \\
\hline 4 & Gıda Mühendisliği & 67 & 67 & 67 & 67 & 2 & 0 & 2 & 2 \\
\hline 5 & Tarım Ekonomisi* & - & $41^{*}$ & 41 & 41 & - & 2 & 1 & 3 \\
\hline 6 & Tarla Bitkileri & 36 & 36 & 36 & 36 & 0 & 0 & 0 & 1 \\
\hline 7 & Toprak Bilimi ve Bitki Besl. & 36 & 31 & 21 & $0^{* * *}$ & 29 & 21 & 18 & $0^{* *}$ \\
\hline 8 & Zootekni & 36 & 21 & 21 & $0^{* * *}$ & 33 & 17 & 20 & $0^{* *}$ \\
\hline & Bölüm sayısı & & & & $8-3$ & & & & \\
\hline & TOPLAM & 283 & 304 & 294 & 216 & 67 & 63 & 71 & 11 \\
\hline
\end{tabular}

Namık Kemal Üniversitesi Ziraat Fakültesi (Tekirdağ)

Kontenjanlar

İlk Tercihte Açık Kontenjanlar

\begin{tabular}{llcccccccc} 
& Bölümler & 2012 & 2013 & 2014 & 2015 & 2012 & 2013 & 2014 & 201 \\
\hline 1 & Bahçe Bitkileri & 36 & 36 & 36 & 36 & 2 & 0 & 17 & 1 \\
2 & Bitki Koruma & 36 & 36 & 36 & 36 & 0 & 1 & 2 & 2 \\
3 & Biyosistem Mühendisliği & 36 & 36 & 36 & 26 & 1 & 5 & 19 & 1 \\
4 & Gıda Mühendisliği & 67 & 67 & 67 & 67 & 1 & 2 & 1 & 3 \\
5 & Tarım Ekonomisi & 36 & 36 & 36 & 36 & 1 & 3 & 2 & 1 \\
6 & Tarımsal Biyoteknoloji & 36 & 36 & 36 & 31 & 6 & 1 & 13 & 5 \\
7 & Tarla Bitkileri & 36 & 36 & 36 & 36 & 0 & 1 & 5 & 2 \\
8 & Toprak Bilimi ve Bitki Besl. & 36 & 21 & 21 & $0^{* * *}$ & 35 & 12 & 16 & $0^{* *}$ \\
9 & Zootekni & 36 & 31 & 21 & $0^{* * *}$ & 26 & 25 & 17 & $0^{* *}$ \\
& Bölüm sayısı & & & & $9-2$ & & & & \\
& TOPLAM & 355 & 335 & 325 & 268 & 72 & 50 & 92 & 15 \\
\hline
\end{tabular}

Ondokuz Mayıs Üniversitesi Ziraat Fakültesi (Samsun)

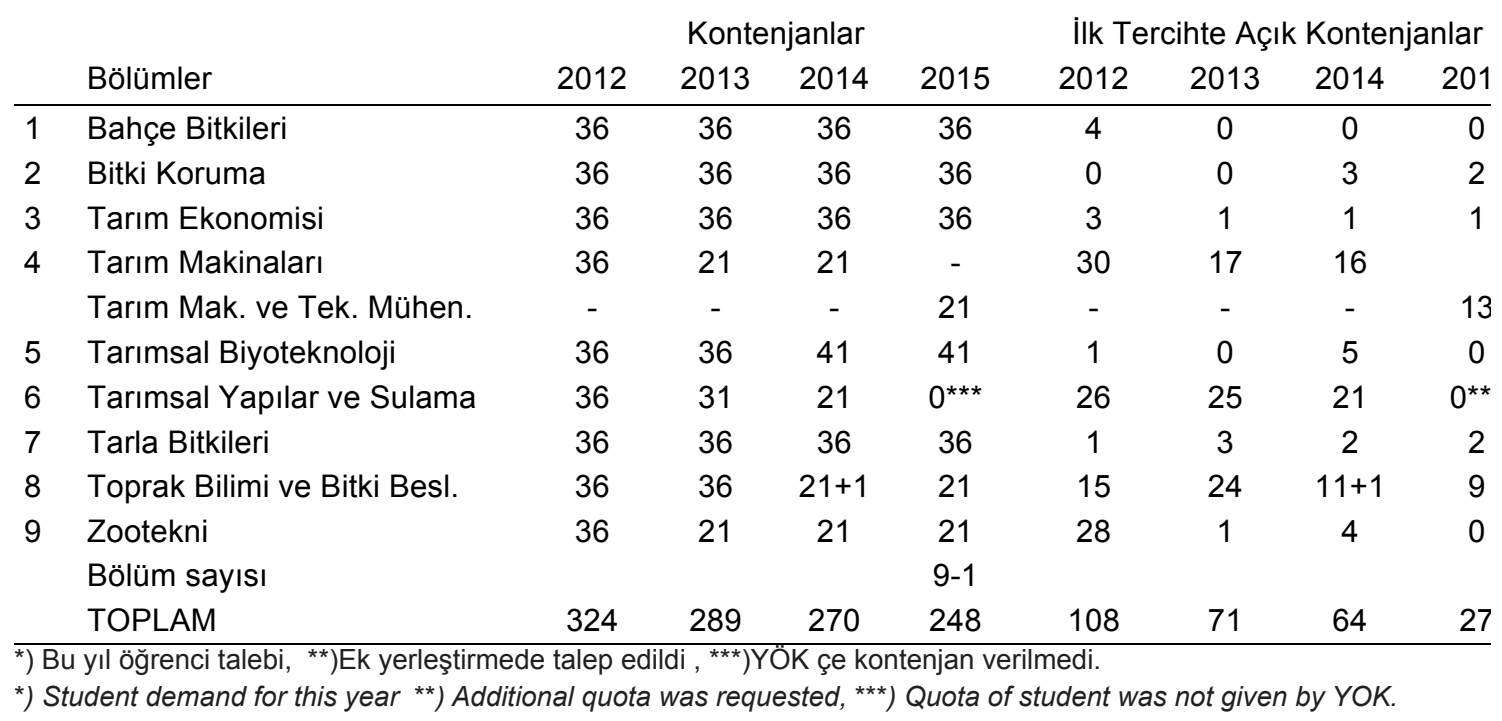


Çizelge 2. (Devamı)

Table 2. (Continued)

\begin{tabular}{|c|c|c|c|c|c|c|c|c|c|}
\hline \multicolumn{10}{|c|}{ Ordu Üniversitesi Ziraat Fakültesi } \\
\hline & \multirow[b]{2}{*}{ Bölümler } & \multicolumn{4}{|c|}{ Kontenjanlar } & \multicolumn{4}{|c|}{ İlk Tercihte Açık Kontenjanlar } \\
\hline & & 2012 & 2013 & 2014 & 2015 & 2012 & 2013 & 2014 & 2015 \\
\hline 1 & Bahçe Bitkileri & 36 & 36 & 36 & 31 & 4 & 1 & 16 & 14 \\
\hline 2 & Bitki Koruma & 36 & 36 & 36 & 36 & 1 & 0 & 0 & 3 \\
\hline 3 & Biyosistem Mühendisliği & - & - & - & - & - & - & - & \\
\hline 4 & Gida Mühendisliği & 36 & 36 & 36 & 41 & 0 & 0 & 0 & 0 \\
\hline 5 & Peyzaj Mimarlığı* & - & $31^{*}$ & 31 & 26 & - & 12 & 14 & 10 \\
\hline 6 & Tarla Bitkileri & 36 & 21 & 31 & 21 & 24 & 2 & 19 & 10 \\
\hline 7 & $\begin{array}{l}\text { Toprak Bilimi ve Bitki } \\
\text { Besleme }\end{array}$ & 36 & $0^{* * *}$ & 0 0** & $0^{\star \star \star}$ & 34 & $0^{\star \star \star}$ & $0^{\star * *}$ & $0^{* * *}$ \\
\hline 8 & $\begin{array}{l}\text { Zootekni } \\
\text { Bölüm sayısı }\end{array}$ & - & $41^{*}$ & 21 & $\begin{array}{l}0 * * * \\
8-3\end{array}$ & - & 38 & 18 & $0^{* * *}$ \\
\hline & TOPLAM & 180 & 201 & 191 & 155 & 63 & 53 & 67 & 37 \\
\hline
\end{tabular}

Selçuk Üniversitesi Ziraat Fakültesi (Konya) Kontenjanlar Ilk Tercihte Açık Kontenjanlar

\begin{tabular}{|c|c|c|c|c|c|c|c|c|}
\hline Bölümler & 2012 & 2013 & 2014 & 2015 & 2012 & 2013 & 2014 & 2015 \\
\hline Bahçe Bitkileri & 36 & 36 & 36 & 36 & 0 & 0 & 1 & 2 \\
\hline Bitki Koruma & 36 & 36 & 36 & 36 & 0 & 1 & 2 & 1 \\
\hline Gıda Mühendisliği & 77 & 77 & 77 & 77 & 1 & 1 & 0 & 4 \\
\hline Peyzaj Mimarlığı & 36 & 36 & 36 & 36 & 2 & 4 & 1 & 2 \\
\hline Tarım Ekonomisi & 36 & 36 & 36 & 36 & 0 & 3 & 3 & 1 \\
\hline Tarım Makinaları & 36 & 21 & 21 & - & 31 & 19 & 17 & \\
\hline Tarım Mak. ve Tek. Mühen. & - & - & - & 21 & - & - & - & 10 \\
\hline Tarımsal Yapılar ve Sulama & 36 & 31 & 21 & 21 & 24 & 21 & 11 & 2 \\
\hline Tarla Bitkileri & 36 & 36 & 36 & 36 & 2 & 1 & 2 & 3 \\
\hline Toprak Bilimi ve Bitki Besl. & 36 & 36 & 31 & 31 & 1 & 1 & 0 & 2 \\
\hline Zootekni & 36 & 36 & 36 & 36 & 1 & 2 & 7 & 2 \\
\hline Bölüm sayısı & & & & 10 & & & & \\
\hline TOPLAM & 399 & 381 & 366 & 366 & 62 & 53 & 44 & 29 \\
\hline
\end{tabular}

\section{Siirt Üniversitesi Ziraat Fakültesi}

Bölümler

Kontenjanlar

İlk Tercihte Açık Kontenjanlar

\begin{tabular}{|c|c|c|c|c|c|c|c|c|}
\hline Bahçe Bitkileri & - & $41^{*}$ & 11 & 21 & - & 33 & 5 & 16 \\
\hline Bitki Koruma* & - & - & - & $41^{*}$ & - & - & - & 30 \\
\hline Biyosistem Mühendisliği & - & - & - & - & - & - & - & - \\
\hline Peyzaj Mimarlığı & - & - & - & - & - & - & - & - \\
\hline Tarım Ekonomisi & - & - & - & - & - & - & - & - \\
\hline Tarımsal Biyoteknoloji & - & - & - & - & - & - & - & - \\
\hline Tarla Bitkileri* & - & $41^{*}$ & 41 & 31 & - & 25 & 30 & 20 \\
\hline Toprak Bilimi ve Bitki Besl. & - & - & - & - & - & - & - & - \\
\hline Zootekni & - & - & - & - & - & - & - & - \\
\hline Bölüm sayısı & & & & $9-6$ & & & & \\
\hline TOPLAM & - & $82^{*}$ & 52 & 93 & - & 58 & 35 & 66 \\
\hline \multicolumn{9}{|c|}{ Süleyman Demirel Üniversitesi Ziraat Fakültesi (Isparta) } \\
\hline & \multicolumn{4}{|c|}{ Kontenjanlar } & \multicolumn{4}{|c|}{ İlk Tercihte Açık Kontenjanlar } \\
\hline Bölümler & 2012 & 2013 & 2014 & 2015 & 2012 & $2013^{3}$ & 2014 & 2015 \\
\hline Bahçe Bitkileri & 36 & 36 & 36 & 36 & 0 & 0 & 0 & 1 \\
\hline Bitki Koruma & 36 & 36 & 36 & 36 & 1 & 0 & 1 & 1 \\
\hline Tarım Ekonomisi & 36 & 36 & 36 & 36 & 2 & 0 & 1 & 2 \\
\hline Tarım Makinaları & 36 & $0^{* * *}$ & $0^{* * *}$ & - & 34 & $0^{\star * \star}$ & $0^{* \star *}$ & - \\
\hline Tarım Mak. ve Tek. Mühen. & - & - & - & 21 & - & - & - & 15 \\
\hline Tarımsal Yapılar ve Sulama & 36 & 21 & 21 & $0^{\star \star \star}$ & 32 & 18 & 19 & $0^{* * *}$ \\
\hline Tarımsal Biyoteknoloji & 36 & 36 & 36 & 36 & 0 & 2 & 3 & 3 \\
\hline Tarla Bitkileri & 36 & 36 & 36 & 36 & 0 & 0 & 1 & 0 \\
\hline Toprak Bilimi ve Bitki Besl. & 36 & 36 & 31 & $0^{* \star \star}$ & 3 & 4 & 24 & $0^{* \star *}$ \\
\hline Zootekni & 57 & 31 & 21 & $0^{* * *}$ & 49 & 22 & 13 & $0^{* * *}$ \\
\hline Bölüm sayısı & & & & $9-3$ & & & & \\
\hline TOPLAM & 345 & 268 & 253 & 201 & 121 & 46 & 62 & 22 \\
\hline
\end{tabular}

*) Bu yıl öğrenci talebi, ${ }^{* *}$ )Ek yerleştirmede talep edildi , ${ }^{* * *}$ )YÖK çe kontenjan verilmedi.

*) Student demand for this year ${ }^{* *}$ ) Additional quota was requested, $\left.{ }^{* *}\right)$ Quota of student was not given by YOK. 
Çizelge 2. (Devamı)

Table 2. (Continued)

\begin{tabular}{|c|c|c|c|c|c|c|c|c|c|}
\hline \multicolumn{10}{|c|}{ Şırnak Üniversitesi Ziraat Fakültesi } \\
\hline & Bölümler & 2012 & 2013 & 2014 & 2015 & 2012 & 2013 & 2014 & 2015 \\
\hline 1 & Bahçe Bitkileri* & & & $31^{*}$ & 21 & & & 27 & 18 \\
\hline 2 & Bitki Koruma & & & - & - & & & - & - \\
\hline 3 & Biyosistem Mühendisliği & & & - & - & & & - & - \\
\hline 4 & Gıda Mühendisliği & & & - & - & & & - & - \\
\hline 5 & Peyzaj Mimarlığı & & & - & - & & & - & - \\
\hline 6 & Su Ürünleri Mühendisliği & & & - & - & & & - & - \\
\hline 7 & Tarım Ekonomisi & & & - & - & & & - & - \\
\hline 8 & Tarımsal Biyoteknoloji & & & - & - & & & - & - \\
\hline 9 & Tarla Bitkileri & & & - & - & & & - & - \\
\hline 10 & Toprak Bilimi ve Bitki Besl. & & & - & - & & & - & - \\
\hline \multirow[t]{3}{*}{11} & Zootekni & & & - & - & & & - & - \\
\hline & Bölüm sayısı & & & & $11-10$ & & & & \\
\hline & TOPLAM & & & 31 & 21 & & & 27 & 18 \\
\hline \multicolumn{10}{|c|}{ Uludağ Üniversitesi Ziraat Fakültesi (Bursa) } \\
\hline & Bölümler & \multicolumn{4}{|c|}{ Kontenjanlar } & $\begin{array}{c}\text { İlk Te } \\
2012 \\
\end{array}$ & $\begin{array}{c}\text { cihte A } \\
2013 \\
\end{array}$ & $\begin{array}{c}\text { Ik Kont } \\
2014 \\
\end{array}$ & $\begin{array}{r}\text { janlar } \\
2015 \\
\end{array}$ \\
\hline 1 & Bahçe Bitkileri & 36 & 36 & 36 & 36 & 3 & 0 & 2 & 2 \\
\hline 2 & Bitki Koruma & 36 & 36 & 36 & 36 & 0 & 0 & 3 & 0 \\
\hline 3 & Biyosistem Mühendisliği & 36 & 36 & $36+1$ & $36+1$ & 0 & 1 & 0 & $4+1$ \\
\hline 4 & Gıda Mühendisliği & 67 & 67 & 67 & 67 & 2 & 1 & 3 & 3 \\
\hline 5 & Tarım Ekonomisi & 36 & 36 & 36 & 36 & 5 & 0 & 0 & 0 \\
\hline 6 & Tarla Bitkileri & 36 & 36 & 36 & 36 & 0 & 1 & 2 & 0 \\
\hline 7 & Toprak Bilimi ve Bitki Besl. & 36 & 36 & $31+1$ & $31+1$ & 1 & 1 & $1+1$ & $2+1$ \\
\hline \multirow[t]{3}{*}{8} & Zootekni & 36 & 36 & $31+1$ & 31 & 1 & 0 & $1+1$ & 0 \\
\hline & Bölüm sayısı & & & & 8 & & & & \\
\hline & TOPLAM & 319 & 319 & 312 & 311 & 12 & 4 & 14 & 13 \\
\hline
\end{tabular}

Yüzüncü Yıl Üniversitesi Ziraat Fakültesi (Van)

Bölümler

Kontenjanlar İlk Tercihte Açık Kontenjanlar

\begin{tabular}{llcccccccc}
\hline 1 & Bahçe Bitkileri & 36 & 36 & 36 & 36 & 12 & 9 & 13 & 24
\end{tabular}

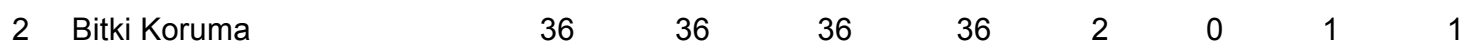

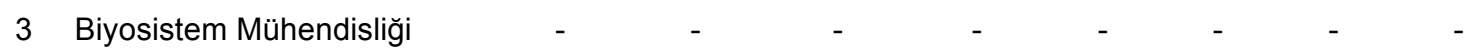

4 Peyzaj Mimarlığı

5 Tarım Ekonomisi

6 Tarımsal Biyoteknoloji*

7 Tarla Bitkileri

8 Toprak Bilimi ve Bitki Besl.

9 Zootekni

Bölüm sayısı

TOPLAM

$\begin{array}{ccc}2012 & 2013 & 2014 \\ 36 & 36 & 36 \\ 36 & 36 & 36 \\ - & - & \end{array}$

) Bu yıl öğrenci talebi, $\left.{ }^{* *}\right)$ Ek yerleştirmede talep edildi , ${ }^{* * *}$ )YÖK çe kontenjan verilmedi.

*) Student demand for this year ${ }^{* *}$ ) Additional quota was requested, $\left.{ }^{* *}\right)$ Quota of student was not given by YOK.

\section{Ziraat ve Doğa Bilimleri Fakülteleri}

Ülkemizde ziraat ve doğa bilimleri fakültesi adıyla 6 fakülte bulunmaktadır. Bu fakültelerde bulunan bölümler, kontenjanlar ve ilk tercih

döneminde açık kalan kontenjanlar Çizelge 3'de özetlenmiştir. 
Çizelge 3. Ziraat ve Doğa Bilimleri Fakültelerinde bulunan bölümler, kontenjanlar ve ilk tercih döneminde açık kalan kontenjanlar

Table 3. Departments, announced and unfilled quotas of the Faculties of Agriculture and Natural Sciences

\begin{tabular}{|c|c|c|c|c|c|c|c|c|c|}
\hline \multicolumn{10}{|c|}{ Abant İzzet Baysal Üniversitesi Ziraat ve Doğa Bilimleri Fakültesi (Bolu) } \\
\hline \multirow{2}{*}{\multicolumn{2}{|c|}{ 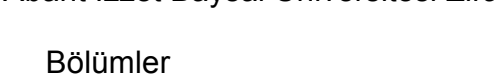 }} & \multicolumn{4}{|c|}{ Kontenjanlar } & \multicolumn{4}{|c|}{ İlk Tercihte Açık Kontenjanlar } \\
\hline & & 2012 & 2013 & 2014 & 2015 & 2012 & 2013 & 2014 & 2015 \\
\hline 1 & Bahce Bitkileri & & & - & - & & & - & - \\
\hline 2 & Bitki Koruma & & & _ & $41^{*}$ & & & & 1 \\
\hline 3 & Kanatlı Hayvan Yetistiriciliği & & & _ & $26^{*}$ & & & & 21 \\
\hline 4 & Tarla Bitkileri* & & & $31^{*}$ & 31 & & & 3 & 2 \\
\hline 5 & Tohum Bilimleri ve Teknolojisi & & & - & - & & & - & - \\
\hline 6 & Yaban Hayatı Ekolojisi ve Yönt. & & & - & - & & & - & - \\
\hline & Bölüm sayısı & & & & $6-3$ & & & & \\
\hline & TOPLAM & & & 31 & 98 & & & 3 & 24 \\
\hline
\end{tabular}

Bilecik Şeyh Edebali Üniversitesi Tarım Bilimleri ve Teknolojileri Fakültesi (Ziraat ve Doğa Bilimleri olarak 2015 'te değiştirildi

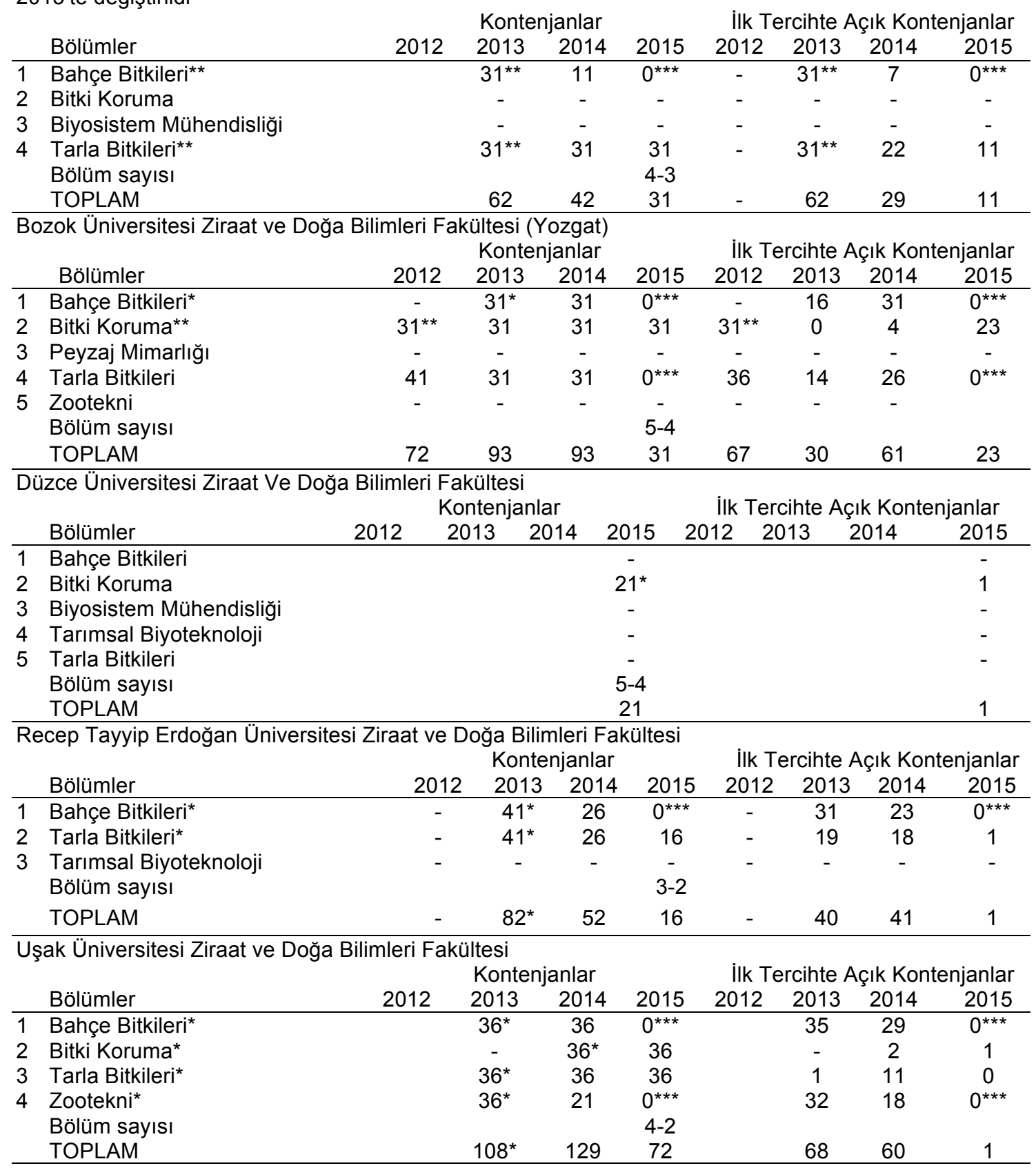

*) Bu yıl öğrenci talebi, ${ }^{* *}$ )Ek yerleştirmede talep edildi , $\left.{ }^{* * *}\right)$ YÖK çe kontenjan verilmedi.

*) Student demand for this year ${ }^{* *}$ ) Additional quota was requested, $\left.{ }^{* *}\right)$ Quota of student was not given by YOK. 


\section{Tarım Bilimleri ve Teknolojileri Fakülteleri}

Ülkemizde tarım bilimleri ve teknolojileri fakültesi adıyla 1 fakülte bulunmaktadır. Bu fakültede bulunan bölümler, kontenjanlar ve ilk tercih döneminde açık kalan kontenjanlar Çizelge 4'de özetlenmiştir.

\section{Tarım Bilimleri Fakülteleri}

Ülkemizde tarım bilimleri fakültesi adıyla 1 fakülte bulunmaktadır. Bu fakülte 2015 yılında Muğla Sıtkı Koçman Üniversitesi Fethiye Tarım Bilimleri Fakültesi adıyla açılmıştır. Henüz hangi bölümlerin açılacağı ve/veya açıldığı web sayfasında bulunmamaktadır.

\section{Tarım ve Doğa Bilimleri Fakülteleri}

Ülkemizde tarım ve doğa bilimleri fakültesi adıyla 1 fakülte bulunmaktadır.

\section{Hayvansal Üretim Yüksekokulları}

Ülkemizde 4 yılık hayvansal üretim yüksekokulu adıyla 2 yüksekokul bulunmaktadır. $\mathrm{Bu}$ yüksekokullarda bulunan bölümler, kontenjanlar ve ilk tercih döneminde açık kalan kontenjanlar Çizelge 5'de özetlenmiştir.

Ülkemizde ziraat fakültesi adıyla 29 fakülte bulunmaktadır. Bu fakültelerde bulunan bölümler, kontenjanlar ve ilk tercih döneminde açık kalan kontenjanlar Çizelge 6'de (Çiftçi 2013; Anonim 2014; Anonim 2015) verilmiştir.

Çizelge 4. Tarım Bilimleri ve Teknolojileri Fakültesinde bulunan bölümler, kontenjanlar ve ilk tercih döneminde açık kalan kontenjanlar

Table 4. Departments, announced and unfilled quotas of the Faculties of Agricultural Sciences and Technologies

\begin{tabular}{|c|c|c|c|c|c|c|c|c|c|}
\hline \multicolumn{10}{|c|}{ Niğde Üniversitesi Tarım Bilimleri ve Teknolojileri Fakültesi } \\
\hline & \multirow[b]{2}{*}{ Bölümler } & \multicolumn{4}{|c|}{ Kontenjanlar } & \multicolumn{4}{|c|}{ İlk Tercihte Açık Kontenjanlar } \\
\hline & & 2012 & 2013 & 2014 & 2015 & 2012 & 2013 & 2014 & 2015 \\
\hline 1 & Bitkisel Üretim ve Teknolojileri* & - & $31^{*}$ & 31 & 31 & - & 2 & 2 & 0 \\
\hline \multirow[t]{3}{*}{2} & Tarımsal Genetik Mühendisliği* & - & $31^{*}$ & 31 & 31 & - & 0 & 0 & 0 \\
\hline & Bölüm sayısı & & & & $2-0$ & & & & \\
\hline & TOPLAM & - & 62 & 62 & 62 & - & 2 & 2 & \\
\hline
\end{tabular}

*) Bu yıl öğrenci talebi

*) Student demand for this year

Çizelge 5. Hayvansal Üretim Yüksekokullarında bulunan bölümler, kontenjanlar ve ilk tercih döneminde açık kalan kontenjanlar

Table 5. Departments, announced and unfilled quotas of the Schools of Animal Production

\begin{tabular}{|c|c|c|c|c|c|c|c|c|c|}
\hline \multicolumn{10}{|c|}{ Ağrı İbrahim Çeçen Üniversitesi Celal Oruç Hayvansal Üretim Yüksekokulu } \\
\hline & \multirow[b]{2}{*}{ Bölümler } & \multicolumn{4}{|c|}{ Kontenjanlar } & \multicolumn{4}{|c|}{ İlk Tercihte Açık Kontenjanlar } \\
\hline & & 2012 & 2013 & 2014 & 2015 & 2012 & 2013 & 2014 & 2015 \\
\hline \multirow[t]{3}{*}{1} & Hayvansal Üretim Y.O. & & 52 & 21 & 31 & & 41 & 5 & 12 \\
\hline & Bölüm sayısı & & & & $1-0$ & & & & \\
\hline & TOPLAM & & 52 & 21 & 31 & & 41 & 5 & 12 \\
\hline \multicolumn{10}{|c|}{ Bozok Üniversitesi Hayvansal Üretim Yüksek Okulu } \\
\hline & & \multicolumn{4}{|c|}{ Kontenjanlar } & \multicolumn{4}{|c|}{ İlk Tercihte Açık Kontenjanlar } \\
\hline & Bölümler & 2012 & 2013 & 2014 & 2015 & 2012 & 2013 & 2014 & 2015 \\
\hline \multirow[t]{3}{*}{1} & Hayvansal Üretim Y.O. & & & & & & & & \\
\hline & Bölüm sayısı & & & & $1-1$ & & & & \\
\hline & TOPLAM & & & & & & & & \\
\hline
\end{tabular}


Çizelge 6. Üniversitelerin Ziraat Fakültelerinde bulunan bölümler, kontenjanlar ve ilk tercih döneminde açık kalan kontenjanlar

Table 6. Departments and their announced and unfilled quotas of Faculties Of Agriculture of Universities

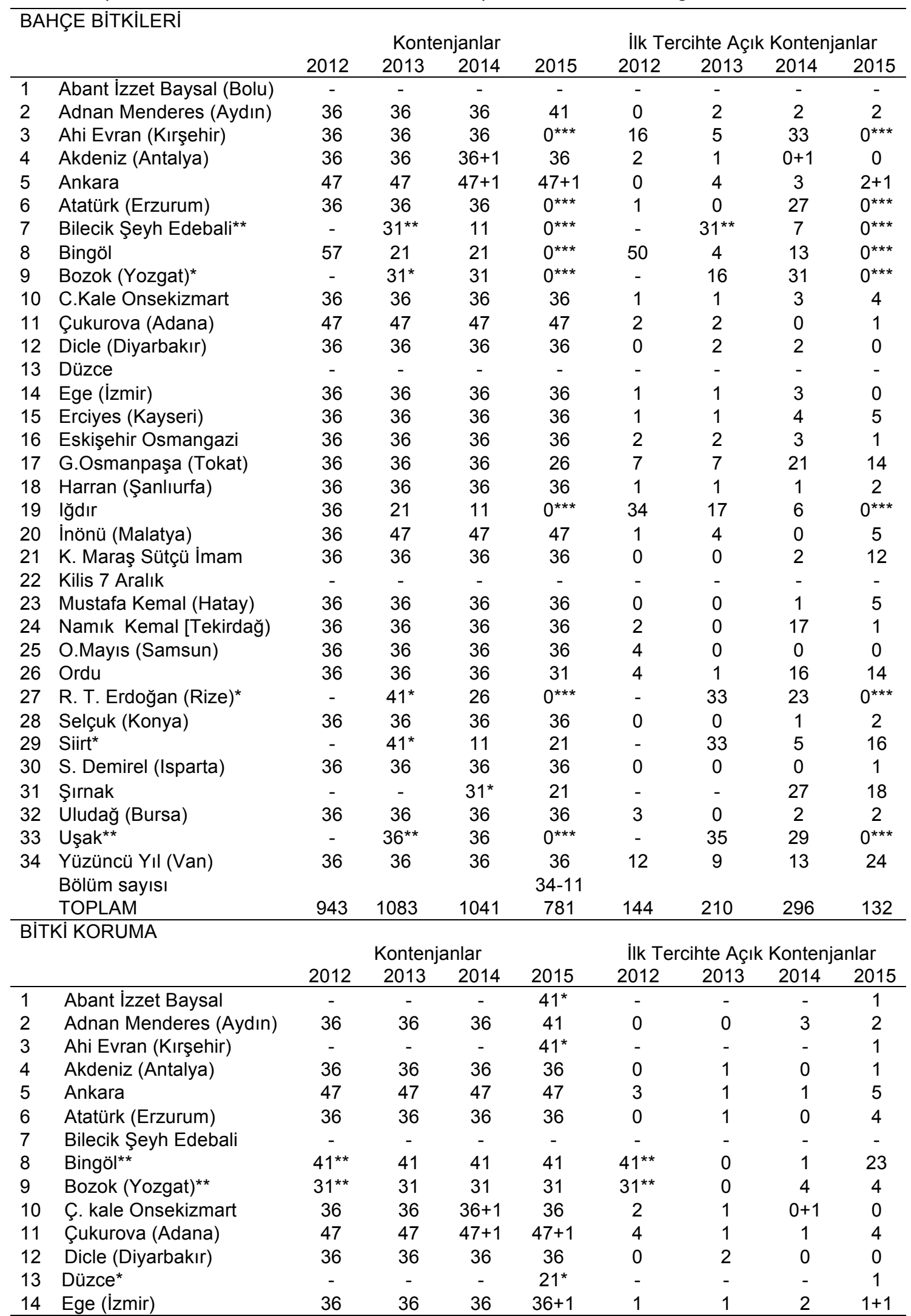

$\left.{ }^{*}\right)$ Bu yıl öğrenci talebi, $\left.{ }^{* *}\right)$ Ek yerleştirmede talep edildi , $\left.{ }^{* * *}\right)$ YÖK çe kontenjan verilmedi.

*) Student demand for this year ${ }^{* *}$ ) Additional quota was requested, $\left.{ }^{* *}\right)$ Quota of student was not given by YOK. 
Çizelge 6. (Devamı)

Table 6. (Continued)

\begin{tabular}{|c|c|c|c|c|c|c|c|c|c|}
\hline \multicolumn{10}{|c|}{ BITKI KORUMA } \\
\hline & & \multicolumn{4}{|c|}{ Kontenjanlar } & \multicolumn{4}{|c|}{ İlk Tercihte Açık Kontenjanlar } \\
\hline & & 2012 & 2013 & 2014 & 2015 & 2012 & 2013 & 2014 & 2015 \\
\hline 15 & Erciyes (Kayseri) & 36 & 36 & 36 & 36 & 2 & 3 & 1 & 0 \\
\hline 16 & Eskişehir Osmangazi & - & - & - & - & - & - & - & - \\
\hline 17 & G. Osmanpaşa (Tokat) & 36 & 36 & 36 & 36 & 0 & 1 & 2 & 2 \\
\hline 18 & Harran (Şanlıurfa) & 36 & 36 & 36 & 36 & 1 & 1 & 0 & 3 \\
\hline 19 & Iğdır & 36 & 36 & 41 & 26 & 4 & 0 & 23 & 17 \\
\hline 20 & İnönü (Malatya) & - & - & $31^{*}$ & 31 & - & - & 1 & 2 \\
\hline 21 & K. Maraş Sütçü İmam & 36 & 36 & 36 & 36 & 2 & 2 & 0 & 2 \\
\hline 22 & M. Kemal (Hatay) & 36 & 36 & 36 & 36 & 1 & 0 & 0 & 0 \\
\hline 23 & N. Kemal (Tekirdağ) & 36 & 36 & 36 & 36 & 0 & 1 & 2 & 2 \\
\hline 24 & O. Mayıs (Samsun) & 36 & 36 & 36 & 36 & 0 & 0 & 3 & 2 \\
\hline 25 & Ordu & 36 & 36 & 36 & 36 & 1 & 0 & 0 & 3 \\
\hline 26 & Selçuk (Konya) & 36 & 36 & 36 & 36 & 0 & 1 & 2 & 1 \\
\hline 27 & Siirt $^{*}$ & - & - & - & $41^{*}$ & - & - & - & 30 \\
\hline 28 & S. Demirel (Isparta) & 36 & 36 & 36 & 36 & 1 & 0 & 1 & 1 \\
\hline 29 & Şırnak & - & - & - & - & - & - & - & - \\
\hline 30 & Uludağ (Bursa) & 36 & 36 & 36 & 36 & 0 & 0 & 3 & 0 \\
\hline 31 & Uşak & - & - & 36 & 36 & - & - & 2 & 1 \\
\hline \multirow[t]{3}{*}{32} & Yüzüncü Yıl (Van) & 36 & 36 & 36 & 36 & 2 & 0 & 1 & 1 \\
\hline & Bölüm sayısı & & & & $32-5$ & & & & \\
\hline & TOPLAM & 850 & 850 & 924 & 1058 & 96 & 17 & 54 & 155 \\
\hline
\end{tabular}

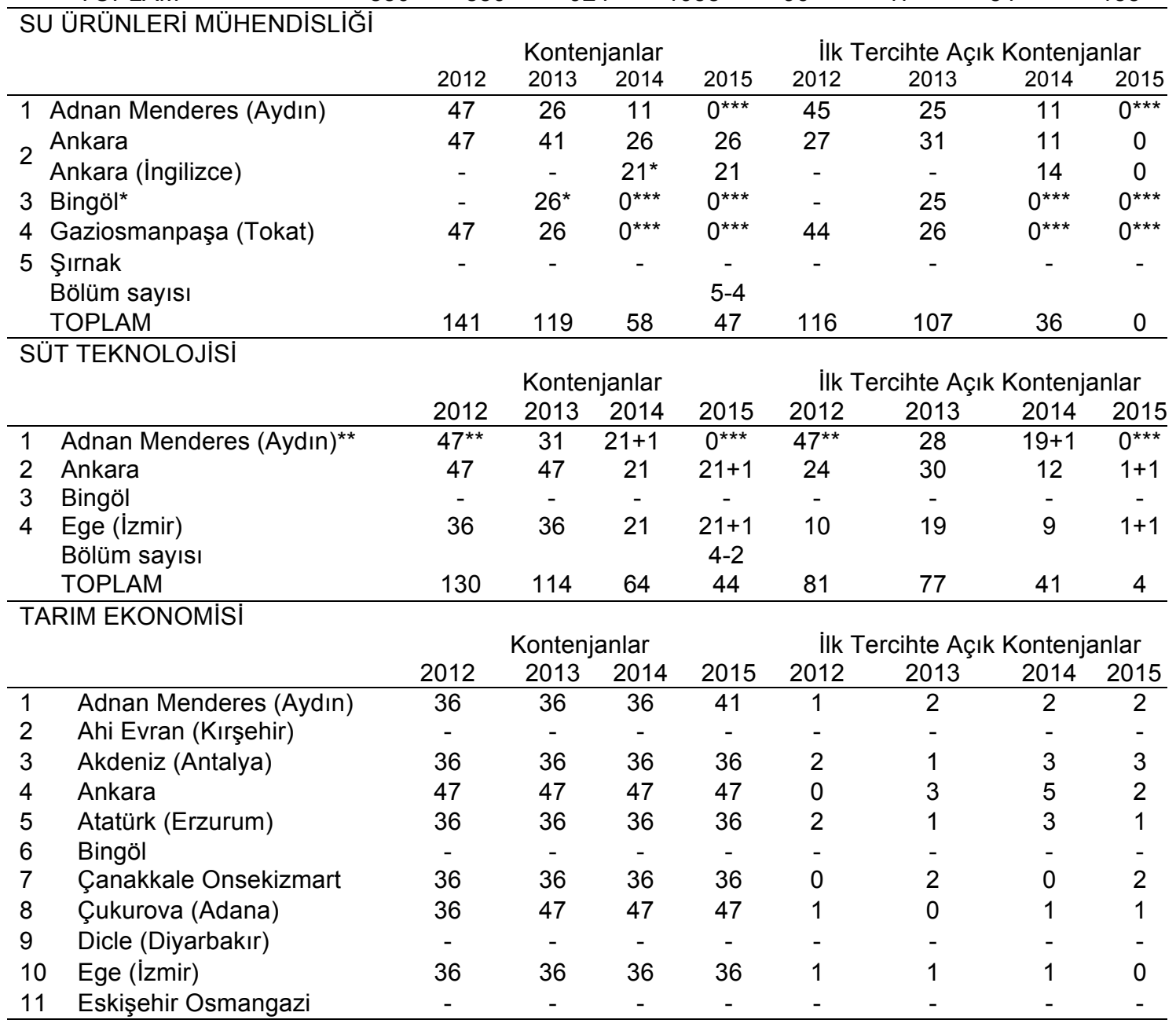

*) Bu yıl öğrenci talebi, ${ }^{* *}$ )Ek yerleştirmede talep edildi , ${ }^{* * *}$ )YÖK çe kontenjan verilmedi.

*) Student demand for this year ${ }^{* *}$ ) Additional quota was requested, ${ }^{* *}$ ) Quota of student was not given by YOK. 
Çizelge 6. (Devamı)

Table 6. (Continued)

\begin{tabular}{|c|c|c|c|c|c|c|c|c|c|}
\hline \multicolumn{10}{|c|}{ TARIM EKONOMISI } \\
\hline & & \multicolumn{4}{|c|}{ Kontenjanlar } & \multicolumn{4}{|c|}{ İlk Tercihte Açık Kontenjanlar } \\
\hline & & 2012 & 2013 & 2014 & 2015 & 2012 & 2013 & 2014 & 2015 \\
\hline$\overline{12}$ & G. Osmanpaşa (Tokat) & 36 & 36 & 36 & 36 & 2 & 1 & 1 & 0 \\
\hline 13 & Harran (Şanlıurfa) & 36 & 36 & 36 & 36 & 0 & 0 & 0 & 1 \\
\hline 14 & Iğdır & 36 & 36 & 36 & 36 & 3 & 6 & 2 & 4 \\
\hline 15 & K. Maraş Sütçü İmam & 36 & 36 & 36 & 36 & 1 & 2 & 3 & 3 \\
\hline 16 & M. Kemal (Hatay)* & - & $41^{*}$ & 41 & 41 & - & 2 & 1 & 3 \\
\hline 17 & N. Kemal (Tekirdağ) & 36 & 36 & 36 & 36 & 1 & 3 & 2 & 1 \\
\hline 18 & 0 , Mayıs (Samsun) & 36 & 36 & 36 & 36 & 3 & 1 & 1 & 1 \\
\hline 19 & Selçuk (Konya) & 36 & 36 & 36 & 36 & 0 & 3 & 3 & 1 \\
\hline 20 & S. Demirel (Isparta) & 36 & 36 & 36 & 36 & 2 & 0 & 1 & 2 \\
\hline 21 & Siirt & - & - & - & - & - & - & - & - \\
\hline 22 & Sırnak & - & - & - & - & - & - & - & - \\
\hline 23 & Ủludağ (Bursa) & 36 & 36 & 36 & 36 & 5 & 0 & 0 & 0 \\
\hline \multirow[t]{2}{*}{24} & Yüzüncü Yıl (Van) & - & - & - & - & - & - & - & - \\
\hline & Bölüm sayısı & & & & $24-7$ & & & & \\
\hline \multicolumn{10}{|c|}{ TARIMSAL BIYYOTEKNOLOJI } \\
\hline & & \multicolumn{4}{|c|}{ Kontenjanlar } & \multicolumn{4}{|c|}{ İlk Tercihte Açık Kontenjanlar } \\
\hline & & 2012 & 2013 & 2014 & 2015 & 2012 & 2013 & 2014 & 2015 \\
\hline$\overline{1}$ & Adnan Menderes (Aydın)* & - & $41^{*}$ & $41+1$ & 41 & - & 1 & $13+1$ & 1 \\
\hline 2 & Ahi Evran (Kırşehir) & 47 & 47 & 47 & 36 & 31 & 3 & 37 & 19 \\
\hline 3 & Atatürk [Erzurum) & 36 & 36 & $36+1$ & $0^{* * *}$ & 17 & 0 & $31+1$ & $0^{* * *}$ \\
\hline 4 & Bingöl & - & - & - & - & - & - & - & - \\
\hline 5 & Çanakkale Onsekizmart & 36 & 36 & 36 & 36 & 1 & 2 & 1 & 3 \\
\hline 6 & Düzce & - & - & - & - & - & - & - & - \\
\hline 7 & Erciyes (Kayseri) & 36 & 36 & 36 & 26 & 5 & 0 & 22 & 0 \\
\hline 8 & Eskişehir Osmangazi** & $41^{* *}$ & 41 & 41 & 41 & $41^{\star *}$ & 1 & 1 & 2 \\
\hline 9 & Namık Kemal (Tekirdağ) & 36 & 36 & 36 & 31 & 6 & 1 & 13 & 5 \\
\hline 10 & Ondokuz Mayıs (Samsun) & 36 & 36 & 41 & 41 & 1 & 0 & 5 & 0 \\
\hline 11 & R.T. Erdoğan (Rize & & & - & - & & - & - & - \\
\hline 12 & S. Demirel (Isparta) & 36 & 36 & 36 & 36 & 0 & 2 & 3 & 3 \\
\hline 13 & Siirt & - & - & - & - & - & - & - & - \\
\hline 14 & Şırnak & - & - & - & - & - & - & - & - \\
\hline \multirow[t]{3}{*}{15} & Yüzüncü Yıl & - & $31^{*}$ & 11 & $0 * * *$ & - & 27 & 5 & 0 *** \\
\hline & Bölüm sayısı & & & & $15-6$ & & & & \\
\hline & TOPLAM & 263 & 376 & 363 & 288 & 102 & 37 & 133 & 33 \\
\hline \multicolumn{10}{|c|}{ TOPRAK BİLİMI VE BITTKI BESLEME } \\
\hline & & \multicolumn{4}{|c|}{ Kontenjanlar } & \multicolumn{4}{|c|}{ İlk Tercihte Açık Kontenjanlar } \\
\hline & & 2012 & 2013 & 2014 & 2015 & 2012 & 2013 & 2014 & 2015 \\
\hline 1 & Adnan Menderes (Aydın) & 36 & 36 & 36 & 31 & 2 & 4 & 22 & 9 \\
\hline 2 & Ahi Evran (Kırşehir) & - & - & - & - & - & - & - & - \\
\hline 3 & Akdeniz (Antalya) & 36 & 36 & 31 & 31 & 0 & 1 & 0 & 0 \\
\hline 4 & Ankara & 47 & 47 & 41 & $41+1$ & 1 & 0 & 5 & $2+1$ \\
\hline 5 & Atatürk (Erzurum) & 36 & $0^{\star \star *}$ & $0^{* * *}$ & $0^{* * *}$ & 35 & $0^{* * *}$ & $0^{* * *}$ & $0^{* * *}$ \\
\hline 6 & Bingöl ${ }^{* *}$ & - & $36^{* *}$ & $0^{* * *}$ & $0^{\star \star *}$ & - & 30 & $0^{\star \star *}$ & $0^{* * *}$ \\
\hline 7 & Çanakkale Onsekizmart & 36 & 36 & 26 & $0^{\star \star *}$ & 19 & 20 & 23 & $0^{* * *}$ \\
\hline 8 & Çukurova (Adana) & 47 & 47 & 41 & 41 & 0 & 0 & 2 & 0 \\
\hline 9 & Dicle (Diyarbakır) & - & - & - & - & - & - & - & - \\
\hline 10 & Ege (İzmir) & 36 & 36 & 31 & 31 & 1 & 0 & 4 & 1 \\
\hline 11 & Erciyes & - & - & - & - & - & - & - & - \\
\hline 12 & Eskişehir Osmangazi & - & - & - & - & - & - & - & - \\
\hline 13 & G. Osmanpaşa (Tokat) & 36 & 21 & 21 & $0^{* * *}$ & 32 & 19 & 17 & 0 *** \\
\hline 14 & Harran (Şanlıurfa) & 36 & 36 & 31 & 21 & 4 & 13 & 19 & 6 \\
\hline 15 & Iğdır & - & - & - & - & - & - & - & - \\
\hline 16 & K. Maraş Sütçü İmam & 36 & 31 & 21 & $0^{\star \star *}$ & 27 & 23 & 21 & 0 *** \\
\hline 17 & Mustafa Kemal (Hatay) & 36 & 31 & 21 & $0^{\star \star *}$ & 29 & 21 & 18 & $0 * * *$ \\
\hline 18 & Namık Kemal (Tekirdağ) & 36 & 21 & 21 & $0^{\star \star *}$ & 35 & 12 & 16 & $0 * * *$ \\
\hline 19 & Ondokuz Mayıs (Samsun) & 36 & 36 & $21+1$ & 21 & 15 & 24 & $11+1$ & 9 \\
\hline 20 & Ordu & 36 & $0^{\star \star \star *}$ & 0 *** & $0^{\star \star *}$ & 34 & $0^{\star \star \star *}$ & $0^{* \star *}$ & $0^{* * *}$ \\
\hline
\end{tabular}

*) Bu yıl öğrenci talebi, ${ }^{* *}$ )Ek yerleştirmede talep edildi , ${ }^{* * *}$ )YÖK çe kontenjan verilmedi.

*) Student demand for this year ${ }^{* *}$ ) Additional quota was requested, ${ }^{* *}$ ) Quota of student was not given by YOK. 
Çizelge 6. (Devamı)

Table 6. (Continued)

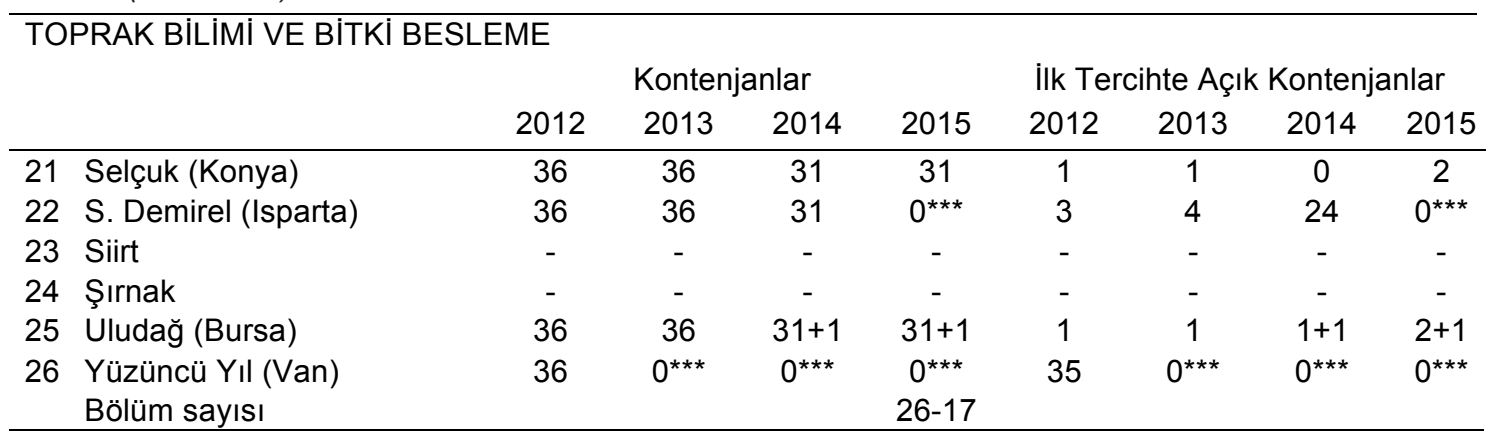

\begin{tabular}{|c|c|c|c|c|c|c|c|c|c|}
\hline \multicolumn{10}{|c|}{ TARIM MAKINALARI } \\
\hline & & 2012 & 2013 & 2014 & 2015 & 2012 & 2013 & 2014 & 2015 \\
\hline 1 & Dicle Diyarbakır) & - & - & - & - & - & - & - & - \\
\hline \multirow[t]{2}{*}{2} & $\begin{array}{l}\text { Harran (Şanlıurfa) } \\
\text { Bölüm sayısı }\end{array}$ & 36 & $0^{* * *}$ & $0^{* * *}$ & $\begin{array}{l}0 * * * \\
2-2\end{array}$ & 36 & $0^{* * *}$ & $0^{* * *}$ & $0^{* \star *}$ \\
\hline & Toplam & 36 & 0 & 0 & 0 & 36 & 0 & 0 & 0 \\
\hline \multicolumn{6}{|c|}{$\begin{array}{c}\text { TARIM MAKINALARI VE TEKNOLOJiLERI MÜHENDISLIĞi } \\
\text { Kontenjanlar }\end{array}$} & \multicolumn{4}{|c|}{ İlk Tercihte Açık Kontenjanlar } \\
\hline & & 2012 & 2013 & 2014 & 2015 & 2012 & 2013 & 2014 & 2015 \\
\hline 1 & Akdeniz (Antalya) & & & & $21^{*}$ & & & & 1 \\
\hline 2 & Ankara & & & & $41^{*}$ & & & & 3 \\
\hline 3 & Atatürk (Erzurum) & & & & $21^{*}$ & & & & 19 \\
\hline 4 & Ç.kale Onsekizmart & & & & $21^{*}$ & & & & 13 \\
\hline 5 & Çukurova (Adana) & & & & $21^{*}$ & & & & 7 \\
\hline 6 & Ege (İzmir) & & & & $31^{*}$ & & & & 2 \\
\hline 7 & O. Mayıs (Samsun) & & & & $21^{*}$ & & & & 13 \\
\hline 8 & Selçuk (Konya) & & & & $21^{*}$ & & & & 10 \\
\hline 9 & S. Demirel (Isparta) & & & & $21^{*}$ & & & & 15 \\
\hline & TOPLAM & & & & 219 & & & & 83 \\
\hline
\end{tabular}

\begin{tabular}{|c|c|c|c|c|c|c|c|c|c|}
\hline \multicolumn{10}{|c|}{ BIYYOSISTEM MÜHENDISLIĞí } \\
\hline & & \multicolumn{4}{|c|}{ Kontenjanlar } & \multicolumn{4}{|c|}{ İlk Tercihte Açık Kontenjanlar } \\
\hline & & 2012 & 2013 & 2014 & 2015 & 2012 & 2013 & 2014 & 2015 \\
\hline 1 & Ad. Menderes (Aydın)* & - & 41 & $52+1$ & $52+1$ & - & 4 & $5+1$ & $2+1$ \\
\hline 2 & Ahi Evran (Kırşehir) & - & - & - & - & - & - & - & - \\
\hline 3 & Bilecik Şeyh Edebali & - & - & - & - & - & - & - & - \\
\hline 4 & Bingöl & - & - & - & - & - & - & - & - \\
\hline 5 & Düzce & - & - & - & - & - & - & - & - \\
\hline 6 & Erciyes (Kayseri) & 36 & 36 & $36+1$ & 26 & 3 & 8 & $26+1$ & 10 \\
\hline 7 & Eskişehir Osmangazi & - & - & - & - & - & - & - & - \\
\hline 8 & G. Osmanpaşa (Tokat) & 36 & 36 & 36 & $0^{* * *}$ & 2 & 28 & 32 & $0^{* * *}$ \\
\hline 9 & Iğdır* & - & $31^{*}$ & 11 & $0^{* * *}$ & - & 30 & 11 & $0^{* * *}$ \\
\hline 10 & K. Maraş Sütçü İmam & 36 & 36 & 36 & $0^{* * *}$ & 6 & 23 & 35 & $0^{* * *}$ \\
\hline 11 & Mustafa Kemal (Hatay) & 36 & 36 & 36 & $0^{* * *}$ & 2 & 23 & 29 & $0^{* * *}$ \\
\hline 12 & Namık Kemal (Tekirdağ) & 36 & 36 & 36 & 26 & 1 & 5 & 19 & 1 \\
\hline 13 & Ordu & - & - & - & - & - & - & - & - \\
\hline 14 & Siirt & - & - & - & - & - & - & - & - \\
\hline 15 & Şırnak & - & - & - & - & - & - & - & - \\
\hline 16 & Uludağ (Bursa) & 36 & 36 & $36+1$ & $36+1$ & 0 & 1 & 0 & $4+1$ \\
\hline \multirow[t]{4}{*}{17} & Yüzüncü Yıl (Van) & - & - & - & - & - & - & - & - \\
\hline & & 6 & 8 & & & & & & \\
\hline & Bölüm sayısı & & & & $17-13$ & & & & \\
\hline & TOPLAM & 216 & 288 & 282 & 142 & 14 & 122 & 159 & 19 \\
\hline
\end{tabular}

*) Bu yıl öğrenci talebi, ${ }^{* *}$ )Ek yerleştirmede talep edildi , $\left.{ }^{* * *}\right)$ YÖK çe kontenjan verilmedi.

$\left.{ }^{*}\right)$ Student demand for this year ${ }^{* *}$ ) Additional quota was requested, ${ }^{* *}$ ) Quota of student was not given by YOK. 
Çizelge 6. (Devamı)

Table 6. (Continued)

\begin{tabular}{|c|c|c|c|c|c|c|c|c|c|}
\hline \multicolumn{10}{|c|}{ TARIMSAL YAPILAR VE SULAMA } \\
\hline & & \multicolumn{4}{|c|}{ Kontenjanlar } & \multicolumn{4}{|c|}{ İlk Tercihte Açık Kontenjanlar } \\
\hline & & 2012 & 2013 & 2014 & 2015 & 2012 & 2013 & 2014 & 2015 \\
\hline 1 & Akdeniz (Antalya) & 36 & 36 & 21 & $0^{* * *}$ & 15 & 29 & 13 & $0^{* \star *}$ \\
\hline 2 & Ankara & 47 & 47 & $31+1$ & 31 & 1 & 8 & $10+1$ & 13 \\
\hline 3 & Atatürk (Erzurum) $)^{* * *}$ & 36 & $0^{* * *}$ & $0^{* \star *}$ & $0 * * *$ & 36 & $0^{* \star *}$ & $0^{* \star *}$ & $0^{\star * *}$ \\
\hline 4 & Çkale Onsekizmart ${ }^{* * *}$ & 36 & $0^{* * *}$ & $0^{* * *}$ & $0^{* * *}$ & 33 & $0^{* * *}$ & $0^{* * *}$ & $0^{* \star *}$ \\
\hline 5 & Çukurova (Adana) & 47 & 47 & $21+1$ & $0^{* * *}$ & 22 & 33 & $14+1$ & $0^{* * *}$ \\
\hline 6 & Dicle (Diyarbakır) & - & - & - & - & - & - & - & - \\
\hline 7 & Ege (İzmir) & 36 & 36 & 31 & $31+1$ & 1 & 1 & 15 & \\
\hline 8 & Harran (Şanlıurfa) & 36 & 31 & 21 & $0^{* * *}$ & 24 & 23 & 16 & $0^{* \star *}$ \\
\hline 9 & O. Mayıs (Samsun) & 36 & 31 & 21 & $0^{* * *}$ & 26 & 25 & 21 & $0^{\star \star *}$ \\
\hline 10 & Selçuk (Konya) & 36 & 31 & 21 & 21 & 24 & 21 & 11 & 2 \\
\hline \multirow[t]{3}{*}{11} & S. Demirel (Isparta) & 36 & 21 & 21 & $0^{* * *}$ & 32 & 18 & 19 & $0^{* * *}$ \\
\hline & Bölüm sayısı & & & & $11-7$ & & & & 15 \\
\hline & TOPLAM & 382 & 280 & 190 & 84 & 240 & 158 & 121 & 30 \\
\hline \multicolumn{10}{|c|}{ TARLA BITKIILERİ } \\
\hline & & \multicolumn{4}{|c|}{ Kontenjanlar } & \multicolumn{4}{|c|}{ İlk Tercihte Açık Kontenjanlar } \\
\hline & & 2012 & 2013 & 2014 & 2015 & 2012 & 2013 & 2014 & 2015 \\
\hline 1 & Abant İ. Baysal (Bolu)* & - & - & 31 & 31 & - & - & 3 & 2 \\
\hline 2 & Adnan Menderes (Aydın) & 36 & 36 & $36+1$ & $41+1$ & 1 & 3 & 1 & $2+1$ \\
\hline 3 & Ahi Evran (Kırşehir) & 36 & 36 & 36 & 36 & 17 & 0 & 14 & 11 \\
\hline 4 & Akdeniz (Antalya) & 36 & 36 & 36 & 36 & 1 & 1 & 1 & 2 \\
\hline 5 & Ankara & 47 & 47 & 47 & $47+1$ & 1 & 1 & 5 & $0+1$ \\
\hline 6 & Atatürk (Erzurum) & 36 & 36 & $36+1$ & 36 & 18 & 5 & $20+1$ & 10 \\
\hline 7 & Bilecik Şeyh Edebali** & - & $31^{* *}$ & 31 & 31 & - & $31^{* *}$ & 22 & 11 \\
\hline 8 & Bingöl & 36 & 36 & 31 & 21 & 19 & 10 & 19 & 12 \\
\hline 9 & Bozok (Yozgat) & 41 & 31 & 31 & $0^{* * *}$ & 36 & 14 & 26 & $0^{* * *}$ \\
\hline 10 & Ç.Kale Onsekizmart & 36 & 36 & 36 & 36 & 0 & 0 & 1 & 1 \\
\hline 11 & Çukurova (Adana) & 47 & 47 & 47 & 47 & 1 & 0 & 1 & 4 \\
\hline 12 & Dicle (Diyarbakır) & 36 & 36 & 36 & 36 & 0 & 0 & 3 & 0 \\
\hline 13 & Düzce & - & - & - & - & - & - & - & - \\
\hline 14 & Ege (İzmir) & 36 & 36 & 36 & 36 & 1 & 1 & 0 & 0 \\
\hline 15 & Erciyes (Kayseri) & 36 & 36 & 36 & 37 & 0 & 1 & 1 & 3 \\
\hline 16 & Eskişehir Osmangazi & 36 & 36 & 36 & 36 & 1 & 1 & 0 & 0 \\
\hline 17 & G. Osmanpaşa (Tokat) & 36 & 36 & 36 & 26 & 17 & 0 & 18 & 13 \\
\hline 18 & Harran (Şanlıurfa) & 36 & 36 & 36 & 36 & 1 & 1 & 1 & 1 \\
\hline 19 & Iğdır & 36 & 36 & 11 & $0 * *$ & 34 & 33 & 6 & $0^{\star * *}$ \\
\hline 20 & K. Maraş Sütçü İmam & 36 & 36 & 36 & 36 & 2 & 3 & 2 & 1 \\
\hline 21 & M, Kemal (Hatay) & 36 & 36 & 36 & 36 & 0 & 0 & 0 & 1 \\
\hline 22 & N. Kemal [Tekirdağ) & 36 & 36 & 36 & 36 & 0 & 1 & 5 & 2 \\
\hline 23 & 0.Mayıs (Samsun) & 36 & 36 & 36 & 36 & 1 & 3 & 2 & 2 \\
\hline 24 & Ordu & 36 & 21 & 31 & 21 & 24 & 2 & 19 & 10 \\
\hline 25 & R. T. Erdoğan (Rize)* & - & $41^{*}$ & 26 & 16 & - & 19 & 18 & 1 \\
\hline 26 & Selçuk (Konya) & 36 & 36 & 36 & 36 & 2 & 1 & 2 & 3 \\
\hline 27 & Siirt $^{*}$ & - & $41^{*}$ & 41 & 31 & - & 25 & 30 & 20 \\
\hline 28 & Şırnak & - & - & - & - & - & - & - & - \\
\hline 29 & S. Demirel (Isparta) & 36 & 36 & 36 & 36 & 0 & 0 & 1 & 0 \\
\hline 30 & Uludağ (Bursa) & 36 & 36 & 36 & 36 & 0 & 1 & 2 & 0 \\
\hline 31 & Uşak* & - & $36^{*}$ & 36 & 36 & - & 1 & 11 & 0 \\
\hline \multirow[t]{3}{*}{32} & Yüzüncü Yıl (Van) & 36 & 36 & 36 & 36 & 13 & 1 & 12 & 25 \\
\hline & Bölüm sayısı & & & & $32-4$ & & & & \\
\hline & TOPLAM & 927 & 1051 & 1049 & 963 & 190 & 159 & 247 & 139 \\
\hline
\end{tabular}

*) Bu yıl öğrenci talebi, ${ }^{* *}$ )Ek yerleştirmede talep edildi , ${ }^{* * *}$ )YÖK çe kontenjan verilmedi.

$\left.{ }^{*}\right)$ Student demand for this year $\left.{ }^{* \star}\right)$ Additional quota was requested, $\left.{ }^{* *}\right)$ Quota of student was not given by YOK. 
Çizelge 6. (Devamı)

Table 6. (Continued)

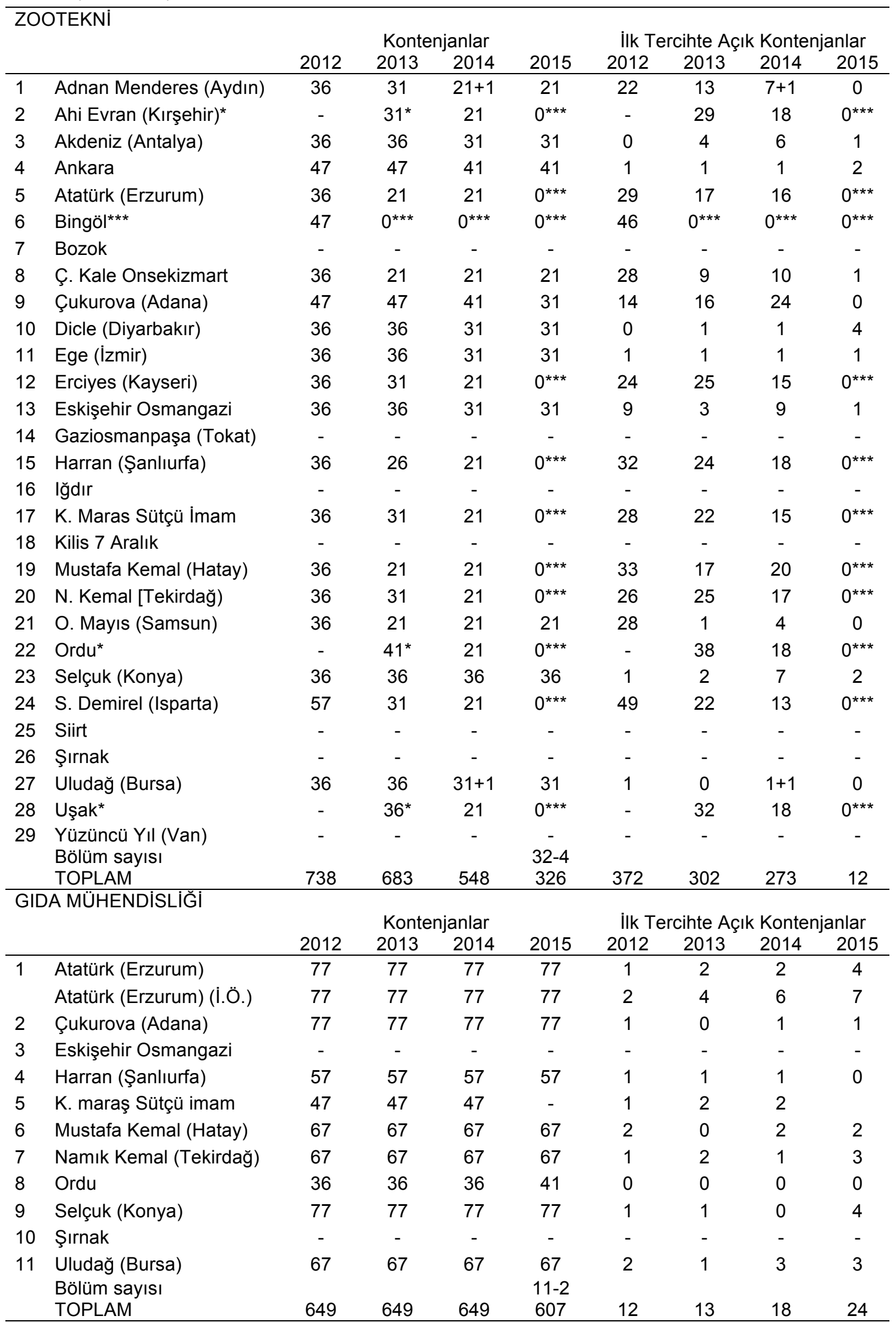

*) Bu yıl öğrenci talebi, $\left.{ }^{* *}\right)$ Ek yerleştirmede talep edildi , $\left.{ }^{* *}\right)$ YÖK çe kontenjan verilmedi.

$\left.{ }^{*}\right)$ Student demand for this year $\left.{ }^{* *}\right)$ Additional quota was requested, $\left.{ }^{* *}\right)$ Quota of student was not given by YOK. 
Çizelge 6. (Devamı)

Table 6. (Continued)

\begin{tabular}{|c|c|c|c|c|c|c|c|c|c|}
\hline \multicolumn{10}{|c|}{ PEYZAJ MIMARLIĞI } \\
\hline & & \multicolumn{4}{|c|}{ Kontenjanlar } & \multicolumn{4}{|c|}{ İlk Tercihte Açık Kontenjanlar } \\
\hline & & 2012 & 2013 & 2014 & 2015 & 2012 & 2013 & 2014 & 2015 \\
\hline$\overline{1}$ & Ad. Menderes (Aydın) & 36 & 36 & 36 & 41 & 1 & 2 & 3 & 3 \\
\hline 2 & Ahi Evran (Kırşehir) & - & - & - & - & - & - & - & - \\
\hline 3 & Akdeniz (Antalya) & 36 & 36 & 36 & 36 & 1 & 2 & 0 & 1 \\
\hline 4 & Ankara & 67 & 67 & 67 & 67 & 6 & 3 & 2 & 4 \\
\hline 5 & Bingöl & - & - & - & - & - & - & - & - \\
\hline 6 & Bozok (Yozgat) & - & - & - & - & - & - & - & - \\
\hline 7 & Çukurova (Adana) & 57 & 57 & 57 & 57 & 1 & 5 & 2 & 7 \\
\hline 8 & Ege (İzmir) & 67 & 67 & 67 & $67+1$ & 0 & 0 & 2 & $4+1$ \\
\hline 9 & Eskişehir Osmangazi & - & - & - & - & - & - & - & - \\
\hline 10 & lğdır & - & - & - & - & - & - & - & - \\
\hline 11 & Ordu* & - & $31^{*}$ & 31 & 26 & - & 12 & 14 & 10 \\
\hline 12 & Selçuk (Konya) & 36 & 36 & 36 & 36 & 2 & 4 & 1 & 2 \\
\hline 13 & Siirt & _ & - & - & _ & - & - & - & - \\
\hline 14 & Sırnak & _ & _ & _ & _ & _ & _ & _ & _ \\
\hline \multirow[t]{3}{*}{15} & Yüzüncü Yıl (Van) & - & - & - & - & - & - & - & - \\
\hline & Bölüm sayısı & & & & $15-8$ & & & & \\
\hline & TOPLAM & 299 & 330 & 330 & 331 & 11 & 28 & 24 & 32 \\
\hline \multicolumn{10}{|c|}{ KANATLI HAYVAN YETIŞTIRICILIGĞi } \\
\hline & & 2012 & 2013 & 2014 & 2015 & 2012 & 2013 & 2014 & 2015 \\
\hline \multirow[t]{3}{*}{1} & Abant İzzet Baysal (Bolu) & & & & 26 & & & & 21 \\
\hline & Bölüm sayısı & & & & $1-0$ & & & & \\
\hline & TOPLAM & & & & 26 & & & & 21 \\
\hline
\end{tabular}

\begin{tabular}{|c|c|c|c|c|c|c|c|c|c|}
\hline \multicolumn{10}{|c|}{ TOHUM BÍLIMLERI VE TEKNOLOJisí } \\
\hline & & 2012 & 2013 & 2014 & 2015 & 2012 & 2013 & 2014 & 2015 \\
\hline \multirow[t]{2}{*}{1} & Abant İzzet Baysal (Bolu) & & & & & & & & \\
\hline & Bölüm sayısı & & & & $1-1$ & & & & \\
\hline \multicolumn{10}{|c|}{ YABAN HAYATI EKOLOJISI VE YÖNETIMI } \\
\hline & & \multicolumn{4}{|c|}{ Kontenjanlar } & \multicolumn{4}{|c|}{ İlk Tercihte Açık Kontenjanlar } \\
\hline & & 2012 & 2013 & 2014 & 2015 & 2012 & 2013 & 2014 & 2015 \\
\hline \multirow[t]{2}{*}{1} & Abant İzzet Baysal (Bolu) & & & & & & & & \\
\hline & Bölüm sayısı & & & & $1-1$ & & & & \\
\hline \multicolumn{10}{|c|}{ HAYVANSAL ÜRETIM YÜKSEKOKULU (4 Yıllık) } \\
\hline & & \multicolumn{4}{|c|}{ Kontenjanlar } & \multicolumn{4}{|c|}{ İlk Tercihte Açık Kontenjanlar } \\
\hline & & 2012 & 2013 & 2014 & 2015 & 2012 & 2013 & 2014 & 2015 \\
\hline 1 & $\begin{array}{l}\text { Ağrı İbrahim Çeçen Celal } \\
\text { Oruç Y.O }\end{array}$ & & $52^{*}$ & 21 & 31 & & 41 & 5 & 12 \\
\hline \multirow[t]{3}{*}{2} & Bozok (Yozgat) & & & & & & & & \\
\hline & Bölüm sayısı & & & & $2-1$ & & & & \\
\hline & TOPLAM & & 52 & 21 & 31 & & 41 & 21 & 12 \\
\hline
\end{tabular}

${ }^{*}$ ) Bu yıl öğrenci talebi, ${ }^{* *}$ )Ek yerleştirmede talep edildi , ${ }^{* * *}$ )YÖK çe kontenjan verilmedi.

$\left.{ }^{*}\right)$ Student demand for this year ${ }^{* *}$ ) Additional quota was requested, ${ }^{* *}$ ) Quota of student was not given by YOK.

Ülkemizde tarımsal yükseköğretimle ilgili fakülteler ve yüksekokullarda bulunan bölümlerin sayısı, YÖK çe kontenjan verilmeyenler, henüz öğrenci talep etmeyenler Çizelge 7'te özetlenmiştir.

\section{Değerlendirme}

Türkiye'de Tarımsal Yükseköğretimin Genel Durumu

Türkiye'de ziraat öğretimi, özellikle 1999 yılından sonra tam bir kaos içerisine girmiştir. Şöyle ki, bugünkü mevzuat içerisinde her hangi bir yasal yaptırımı olmayan ancak sadece "tavsiye" niteliğinde görüş bildirmesi mümkün olan; Ziraat, Orman ve Su Ürünleri Fakülteleri Dekanları ve bu fakültelerden olan Rektörler tarafından oluşturulan "Tarım, Orman ve Su Ürünleri konseyi”, Türkiye'deki ziraat fakültelerinin vereceği eğitime ilişkin, adeta bir üst karar organı gibi, çeşitli kararlar almakta ve bunların uygulanmasını takip etmektedir.

Bilindiği gibi ziraat fakülteleri 1999 yılına kadar bölümlere öğrenci almakta idi, öğrenciler tercihlerini yaparken bölüm tercihi yapıp ona 
göre ÖSYM tarafından yerleştiriliyorlardı. Belki daha önce de bulunan ancak, 90'lı yılların ortasında işlerlik kazanan Tarım, Orman ve Su Ürünleri Konseyi bölümler yerine lisans programlarının oluşturulmasına yani, ziraat fakültelerinin bitkisel üretim, hayvansal üretim, tarım teknolojisi, gıda mühendisliği ve peyzaj mimarlığı lisans programı olmak üzere 5 lisans programından oluşmasına karar vermiştir. Hemen hemen aynı Hocalarımızın yer aldığı Konsey, lisans programlarına kayıt olan öğrenciler henüz mezun olmadan, bu kez $3+1$ sistemine geçilmesini ve 2003 eğitim yılında bu sisteme göre öğrenci alınmasını kararlaştırmıştır. Tarım Orman ve Su Ürünleri Konseyi 2008 yılında da Bölüm Sistemi eğitim ve öğretim sistemine geçilmesine karar vermiştir.

Ziraat fakültelerinde eğitim ve öğretim sistemi bir kaos içindedir. Bugün fakültemizde, bölüm sistemine göre, lisans programları sistemine göre, ziraat mühendisliği sistemine ve tekrar bölüm sistemine göre kayıt olmuş öğrenciler bulunmaktadır. Aldıkları dersler farklı, ders saatleri farklı, vs. bazı dersler kaldırılmış, bazı derslerin kredileri değişmiştir.

Tarım Orman ve Su Ürünleri Konseyi'nin aldığı ve tüm ziraat fakültelerinde uygulama zorunluluğu getirdiği kararlar sonucunda; Ziraat fakültelerinde merkezileşme, ziraat mühendisliği eğitiminde tekdüzeleşme meydana gelmiştir. Artık, Tarım Orman Su Ürünleri Konseyi, ziraat fakültelerinin uygulayacakları eğitim öğretim sistemlerinden elini çekmelidir. 1980'li yıllara kadar ziraat fakültelerine gelen öğrencilerin büyük bir çoğunluğunun tarımla az çok bir ilgisi ve bilgisi bulunmaktaydı ve ziraat fakültelerine isteyerek gelmekteydiler. Ancak ziraat fakültelerine son yıllarda gelen öğrencilerin büyük çoğunluğunun tarımla hiçbir ilgisi ve bilgisi bulunmamaktadır.

Halen birçok Avrupa ülkesinde ziraat fakültesinde okumanın koşulu olarak, çiftçi çocuğu olunması gibi zorunlu olmayan ancak tercih önceliği sağlayan koşullar bulunmaktadır. Mesleğin öğrenilmesinden çok diplomalı olmanın zorladığı yapı, konu ile ilgi ve beklentisi olmayan kişilerin tercih yapmasına neden olmaktadır.

Ne yazık ki, bazı öğrencilerimiz, kokuyor diye ahıra, ağıla ve kümeslere girmek, mikrop kaparım diye toprağa değmek istememektedirler. Tarımla daha önce hiçbir ilgisi olmayan ve ziraat fakültelerine isteyerek gelmemiş bu öğrencilere, tarımı öğretmek ve sevdirmek oldukça güç olmaktadır.

Çizelge 7. Tarımsal yükseköğretimle ilgili fakülte vd. bulunan bölümlerin toplam sayısı, YÖK'çe kontenjan verilmeyenler, henüz öğrenci talep etmeyenle kontenjanlar ve ilk tercih döneminde açık kalan kontenjanlar Table 7. Total department numbers of agriculturel higher education, numbers of departments without any assigned quotas by YOK (Council of Higher Education), number of departments without quota claims and quotas remaining vacant in their first semester.

\begin{tabular}{llcccc}
\hline & BÖLÜMLER & Sayı & $\begin{array}{c}\text { YÖK } \\
\text { kontenjan } \\
\text { verilmeyen }\end{array}$ & $\begin{array}{c}\text { Henüz } \\
\text { örenci talep } \\
\text { etmeyen }\end{array}$ & $\begin{array}{c}\text { Öğrenci } \\
\text { Talep } \\
\text { eden }\end{array}$ \\
\hline 1 & Bahçe Bitkileri & 34 & 8 & 3 & 23 \\
2 & Bitki Koruma & 32 & 0 & 5 & 27 \\
3 & Bitkisel Üretim ve Teknolojileri & 1 & 0 & 0 & 1 \\
4 & Biyosistem Mühendisliği & 17 & 4 & 9 & 4 \\
5 & Gıda Mühendisliği & 11 & 0 & 2 & 9 \\
6 & Kanatlı Hayvan Yetiştiriciliği & 1 & 0 & 0 & 1 \\
7 & Peyzaj Mimarlığı & 15 & 0 & 8 & 7 \\
8 & Su Ürünleri Mühendisliği & 5 & 3 & 1 & 1 \\
9 & Süt Teknolojisi & 4 & 1 & 1 & 2 \\
10 & Tarım Ekonomisi & 24 & 0 & 7 & 17 \\
11 & Tarım Makinaları & 2 & 2 & 0 & 9 \\
12 & Tarım Makinaları ve Tekn. Mühendisliği & 9 & 0 & 0 & 8 \\
13 & Tarımsal Biyoteknoloji & 14 & 2 & 4 & 1 \\
14 & Tarımsal Genetik Mühendisliği & 1 & 0 & 0 & 3 \\
15 & Tarımsal Yapılar ve Sulama & 12 & 7 & 2 & 28 \\
16 & Tarla Bitkileri & 32 & 2 & 2 & 13 \\
17 & Toprak Bilimi ve Bitki Besleme & 26 & 10 & 7 & 0 \\
18 & Zootekni & 29 & 11 & 5 & 1 \\
19 & Tohum Bilimleri ve Teknolojisi & 1 & 0 & 1 & 164 \\
20 & Yaban Hayatı Ekolojisi ve Yönetimi & 1 & 0 & 1 & 1 \\
21 & Hayvansal Üretim & 2 & 0 & & \\
& & & & & \\
& TOPLAM & 273 & 50 & 59 & \\
\hline
\end{tabular}




\section{Yeni Ziraat Fakültesi Açılması}

1982 yılına kadar ülkemizde 7 adet ziraat fakültesi varken ve bu fakülteler, coğrafik bölgelerimize uygun bir dağılım göstermişken, tarımsal yükseköğretimle ilgili fakülte sayıları 1982 yılında 4, 1983 yılında 1, 1987 yılında 2, 1992 yılında 8, 1995 yılında 1, 2005 yılında 1, 2008 yilında 1, 2010 yilında 2, 2011 yilında 1 ve 2012 yilında 5, 2013 yılında 2, 2015 yılında 3 artarak toplam sayısı 38'e çıkmışıı.

Bunlara ilave olarak, 1 vakıf üniversitesinde tarım ve doğa bilimleri fakültesi, 2 hayvansal üretim yüksekokulu bulunmaktadır.

Mekteb-i Zirayi Şahane, Halkalı Ziraat Mekteb-i Ali'si, Ankara Yüksek Ziraat Mekteb-i ve Yüksek Ziraat Enstitüsü Ziraat Fakülteleri kurulurken, yeterli öğretim üyesi, bu okulların laboratuarları, dershaneleri, kütüphaneleri, öğrenci yurtları ve en önemlisi de ziraat eğitiminin olmazsa olmazı öğrencilerin uygulamaları yapabilecekleri çiftlikleri bulunmaktaydı, Yüksek Ziraat Enstitüsünün kendine ait bir uygulama çiftliği yoktu ancak Enstitünün arazisi ve Atatürk Orman Çiftliği uygulama alanları vardı. Ayrıca Yüksek Ziraat Enstitüsü Ziraat Fakültesi öğrencileri ilk yıl 11 ay süreyle staj yapmak ve staj sonunda gayet ciddi bir şekilde yapılan staj sınavında başarılı olmak zorunda idi. Bu yönetmelik 1953 yılında değiştirilmiş ve staj, sömestre ve yaz tatilleri aralarına dağıtıımıştır.

Bugün ziraat fakültelerinin hemen hemen tamamı yukarıda açıklamaya çalıştığım hiçbir olanağa sahip değilken kurulmuşlardır. Tıp eğitimi için hastaneler ne ise, ziraat eğitimi için de laboratuar ve uygulama çiftlikleri odur.

Bugün, bina, öğrenci yurdu, öğretim üyesi, laboratuvar, araştırma uygulama çiftliği var mı? Aynı ekolojiye sahip birbirine çok yakın olan illerde ziraat fakültesi açılması gerekli mi? Tüm bu soruların cevapları dikkate alınmadan yeni ziraat fakülteleri açılmaktadır.

Ne yazık ki ülkemizde gerek üniversiteler ve gerekse fakülteler siyasi olarak açılmaktadır ve Sayın Rektörlerimiz de görev sürelerinde üniversitelerine açtıkları fakülte sayısı ile gurur duymaktadırlar.

Bugün itibariyle ülkemizde 109 devlet üniversitesi, 76 vakıf üniversitesi olmak üzere toplam 185 üniversite bulunmaktadır. Artık üniversiteler ve bu üniversitelerdeki tarımsal yükseköğretimle ilgili fakülteler ilçelerde kurulmaya başlamıştır. 3 tarımsal yükseköğretimle ilgili fakülte Develi, Bandırma ve Fethiye ilçelerinde açılmıştır.
Iller ve ilçeler, üniversiteye, fakültelere ve/veya meslek yüksekokullarına sahip olmak istemektedirler. Çünkü öğrenci geldiğinde masraf yapacak ekonomi gelişecek, yeteri kadar yurt olmadığından bölgede kiralık evlerin kiraları yükselecektir.

Ülkemizde bulunan ziraat fakülteleri intiyaç duyulandan çok daha fazladır. Ziraat fakülteleri açilırken ülke gerçekleri ve gereksinimleri göz ardı edilmiş, siyasi tercihlerle yan yana bulunan birkaç ilde ziraat fakülteleri açılmıştır. Aynı bölgede bulunan, benzer ekolojiye sahip olan ve birbirlerine çok yakın illerde ziraat fakülteleri açılmasının ülke tarımına ne kazandıracağı ve ne kazandırdığı üzerinde düşünülmesi gerekli bir konudur. Bundan sonra hiçbir ilde ziraat fakültesi açılmamalı hatta mevcutlardan bazıları kapatılmalıdır. Gelecekte, bölümler dolayısı ile fakülteler öğrenci bulamayacaklardır. Fakültelerimiz ve bölümlerimiz bu gerçeği göz önüne alarak, son günlerin moda deyimiyle yol haritalarını gözden geçirmek zorundadırlar. Bu sorun, fakültelerin ve bölümlerin adını değiştirerek, yeni bölümler oluşturarak çözülebilecek bir sorun değildir (Çiftçi, 2013).

Öğrencilerin tercihleri bu şekilde devam ederse ki bunu 15 yıldır yazıyorum ve sunumlarımda anlatıyorum, zaten bu kendiliğinden olacaktır olmaktadır da.

\section{Fakülte İsimlerinin Farklılığı}

Ülkemizde 29 ziraat, 6 ziraat ve doğa bilimleri, 2 tarım bilimleri ve teknolojileri, 1 tarım bilimleri, 1 tarım ve doğa bilimleri fakültesi ile 2 hayvansal üretim yüksekokulu olmak üzere 41 lisans öğretimi yapan tarımsal yükseköğretimle ilgili fakülte ve 4 yıllık yüksekokul bulunmaktadır.

2012 - 2013 eğitim öğretim yılında 2 yıllık meslek yüksekokullarında 376 normal, 73 ikinci öğretim olmak üzere 449 tarımsal yükseköğretimle ilgili program öğrenci talep etmiştir (Çiftçi ve Benlioğlu, 2014). Birçok meslek yüksekokulu, ilçelerde bulunmakta ve bağlı bulunduğu üniversitede ziraat fakültesi bulunmamaktadır.

Ziraat ve doğa bilimleri fakültelerinde ziraatın konumu ne olacaktır? Örneğin, mühendislik ve mimarlık fakültelerindeki gibi, mühendislik dalları ayrı, mimarlık dalları ayrı mı olacak? Yoksa ziraat ve doğa fakültelerinin lisans programları birlikte mi olacaktır? Görülen odur ki, ziraat ve doğa bilimleri fakültelerinde açılan bölümler ziraat fakültelerinde açılan bölümlerle aynıdır. 
İzzet Baysal Üniversitesi Ziraat ve Doğa bilimleri Fakültesi ile Niğde Üniversitesi'nde Tarım Bilimleri Teknolojileri Fakültesi'nde yeni bölümler bulunmaktadır.

Ülkemizde 29 üniversitede ziraat fakültesi olarak eğitim öğretim yapılırken ve fakülte mezunlarına ziraat mühendisi unvanı verileceği belirtilmişken fakültelere böyle farklı adların verilmesi ne kadar doğru olacaktır ve öğrenci tercihlerinde bir kaosa yol açmayacak mıdır?

Bir banka reklamı vardı. Yok birbirimizden farkımız, biz Osmanlı Bankasıyız diye, isim değiştirmekle ne değişecektir?

\section{Fakültelerde Her Bölümün Açılması}

Yeni açılan tarımsal yükseköğretimle ilgili fakülteler, açılır açılmaz bölümler açmakta ve öğrenci talep etmekte hatta lisansüstü programlar açmaktadır.

Tarım Makinaları ve Tarımsal Yapılar ve Sulama Bölümleri

Yıllardır Ankara, Ege ve Çukurova Üniversitelerinin Tarım Makinaları ve Tarımsal Yapılar ve Sulama Bölümleri, ayrıca bir biyosistem mühendisliği bölümü de açmak için çok uğraş vermişlerdir. Hatta bu konuda ZMO ve Ankara Üniversitesi Ziraat Fakültesi birlikte Ankara'da 2 günlük bir çalıştay düzenlemiştir. Bu konu uzun süre konsey ve Fakülte kurullarında tartışımış, bazı Hocalarımız, yeni bölümler açmaktan çekinilmemesi, bölüm sistemine geçilirken yeni lisans programları önerirlerken, başka yeni lisans programlarının da önerilmesini savunmuşlardır.

Bu konuda Ankara, Ege ve Çukurova Üniversitelerinin bu bölümü açmak için yıllarca uğraş vermiş ancak görüldüğü gibi bu fakültelerimizde biyosistem mühendisliği bölümleri yoktur. Bunun da nedeni, YÖK'ün biyosistem mühendisliği lisans programı açılan fakültelerde tarımsal yapılar ve sulama bölümü ile tarımsal makine bölümünün öğrenci alamayacağına ve birleşmelerine karar vermesidir. Yaklaşık 80 yıldır tarımsal yapılar ve sulama bölümü ile tarımsal makine bölümü olarak eğitime devam eden bu bölümlerin ne gibi bir sıkıntıları var idi de biyosistem mühendisliği bölümü için ısrarcı oldular? Gelecekte bu durum büyük sorunlara neden olacak ve eskiye dönüş başlayacaktır. Şimdi fakültelerde, biyosistem mühendisliği, tarım makinaları ile tarım makinaları ve teknolojisi mühendisliği adı altında 3 farklı bölüm bulunmaktadır. Bu konu, durmadan isim değiştirmekle çözülecek bir sorun değildir. Önümüzdeki birkaç yıl içinde bu bölümlerimizi büyük sorunlar beklemektedir. Aynı durum tarımsal yapılar ve sulama bölümünde de önemli bir sorundur.

\section{Süt Teknolojisi ve Su Ürünleri Mühendisliği}

Süt teknolojisi bölümü Ankara ve Ege Üniversiteleri Ziraat Fakültelerinde bile belli oranda öğrenci sıkıntısı çekerken. Yeni açılan fakültelerde süt teknolojisi bölümünün açılması ne kadar doğrudur?

Su ürünleri mühendisliği bölümleri sadece ziraat fakültelerinde bulunmayıp, ziraat fakülteleri olmayan diğer üniversitelerde su ürünleri mühendisliği fakülteleri adı altında öğretim yapılmaktadır. Bu fakültelerde de öğrenci sıkıntısı had safhadadır.

\section{Tarımsal Biyoteknoloji Bölümü}

Yeni açılan bölümlerden olan tarımsal biyoteknoloji bölümü ise, yine eski fakültelerimiz bu bölümü açmamıştır. Genellikle yeni açılan fakülteler bu bölümü açmışlardır. Özellikle biyoteknoloji laboratuarları olan büyük üniversitelerin ziraat fakültelerinin değişik bölümlerinde bitkisel ve hayvansal biyoteknoloji konusunda lisansüstü ve doktora tez çalışmaları başarılı bir şekilde yürütülmekteydi ve yürütülmektedir.

Şimdilik 15 fakültede bulunan tarımsal biyoteknoloji bölümü her yıl öğrenci alacak ve mezun edecektir. 4 - 5 yıl sonra bu öğrenciler nerede ve ne olarak iş bulabileceklerdir. Bu bölümler açılırken ülkemizin kaç tarımsal biyoteknoloji mezununa gereksinimi olduğu hesaplanmış mıdır? Bu bölümün lisans programı olarak değil, lisansüstü program olarak açılması en doğru yol olacaktı.

Gıda Mühendisliği ve Peyzaj Mimarı̆̆ı Bölümleri

1933 yılında açılan Yüksek Ziraat Enstitüsü Ziraat Sanatları Fakültesi olarak yer alan ve 1948 yılından itibaren Ziraat Fakültesi bünyesinde değişik isimlerle bölüm olarak eğitim veren Gıda Mühendisliği ile yine ilk olarak Ziraat Fakültesinde bölüm olarak değişik isimlerle eğitim veren Peyzaj Mimarlı̆̆ı bölümleri bugün kuruluşlarındaki fonksiyonlarında değildirler. A.Ü. Ziraat Fakültesinde yer alan Gıda Mühendisliği Bölümü Mühendislik Fakültesi bünyesine geçmiştir. Peyzaj Mimarlığı Bölümünün de Mimarlık Fakültesi kurulduğunda mimarlık fakültesine geçmesi sürpriz olmayacaktır. Yeni 
açılmış ziraat fakültelerinin bu iki bölümü açmak istemelerini anlamak mümkün değildir.

\section{Tarım Ekonomisi Bölümü}

Ziraat Fakültelerinin diğer bölümleri MF2, MF3 ve MF4 den öğrenci alırken, Tarım Ekonomisi bölümü TM1 den öğrenci almaktadır. Mezunlarına mühendis unvanı verilen bir bölümün TM puanları ile öğrenci talep etmesi ne kadar doğrudur. Ziraat Fakülteleri sosyal bilimlerde değil, fen bilimlerinde yer almaktadır. Diğer bölümler ile tarım ekonomisi bölümlerinin hitap ettiği öğrenci grubu farklıdır. Bu nedenle tarım ekonomisi bölümleri şimdilik öğrenci tercihlerinde pek sorunla karşılaşmamaktadırlar.

Kanatlı Hayvan Yetiştiriciliği, Tohum Bilimleri ve Teknolojisi ve Yaban Hayatı Ekolojisi ve Yönetimi Bölümleri

Abant İzzet Baysal Üniversitesi Ziraat ve Doğa Bilimleri Fakültesi, Kanatı Hayvan Yetiştiriciliği, Tohum Bilimleri ve Teknolojisi ve Yaban Hayatı Ekolojisi ve Yönetimi Bölümleri adları ile 3 yeni bölüm açmış, 2015 - 2016 eğitim ve öğretim yılı için Kanatlı Hayvan Yetiştiriciliği Bölümü için öğrenci talep etmiştir. Ziraat fakülteleri il ve ilçelerde sektöre göre değişik bölümler açması doğru ve sürdürülebilir bir yaklaşım değildir. Bu böyle giderse ilgili fakültelerde onlarca bölüm açmak gerekebilecektir.

Bolu ve çevresi kanatı hayvan yetiştiriciliğine önemli bir ilimizdir. Bugün zaten zootekni bölümlerinde kanatlı hayvan yetiştiriciliği konusu temel eğitim alanlarından birisidir. Dolayısıyla alan uzmanı yetişmiş personele hep gereksinme duyulacağı açıktır. Ancak, kendini bu konuda özel olarak yetiştirmek isteyen meslektaşlarımız zootekni bölümlerimizde yüksek lisans ve doktora yaparak uzmanlaşabilirler. Bölüm açmak, Tarım ve Köyişleri Bakanlığı'nda "Araştırma Enstitüsü" açmaya benzemez. Çünkü bu bölümlerden her yıl yüzlerce öğrenci mezun edilecektir.Bu sektörde kaç ziraat mühendisine gereksinim duyulmaktadır? Kaçına iş ve istihdam olanağı sağlanabilecektir? Bütün bunların, mesleki yetkinlik ve donanımla birlikte düşünülüp ta baştan ele alınması gereklidir.

Böyle plansız ve öngörüsüz bir ivecenlikle bu kapıyı bir kez aralarsak, bunun önüne geçmek mümkün değildir. Bu mantıkla gelecekte sadece tarla, bahçe ve zootekni bölümlerini dikkate alırsak aşağıdaki gibi "bir senaryo" önümüze gelebilir!.....

\section{Zootekni bölümüne ek olarak:}

Büyük Baş Hayvan Yetiştiriciliği,

Küçük Baş Hayvan Yetiştiriciliği,

Arıcılık,

İpek Böcekçiliği,

Kanatlı Hayvan Yetiştiriciliği vd.

Tarla Bitkileri Bölümüne ek olarak;

Serin İklim Tahılları Yetiştiriciliği,

Sıcak İklim Tahılları Yetiştiriciliği,

Yemeklik Baklagil Yetiştiriciliği,

Nişasta Şeker Bitkileri Yetiştiriciliği,

Tütün Illaç Baharat Bitkileri Yetiştiriciliği,

Yağ Bitkileri Yetiştiriciliği,

Lif Kauçuk Bitkileri Yetiştiriciliği,

Yem Bitkileri Yetiştiriciliği,

Mera Yönetimi,

Bitki Islahı vd.

Bahçe Bitkileri Bölümüne ek olarak;

Meyve Yetiştiriciliği,

Sebze Yetiştiriciliği,

Bağcılık,

Süs Bitkileri,

Seracılık...

gibi yeni bölümlerinin açılması gündeme gelebilecektir.

Böyle bir yol bir kere açılırsa o yoldan nasıl geri dönülecektir?

Ayrıca, gelecekte koyun yetiştiriciliği, keçi yetiştiriciliği, ördek yetiştiriciliği, buğday yetiştiriciliği, şeker pancarı yetiştiriciliği, pamuk yetiştiriciliği vd. birçok bölüm açma isteği gelirse ne yapılacaktır? Fakültelerimizde öğrencilerimize 140 kredi - saat ders verilmektedir. Böylesi yeni bölümler, bu ölçekteki ders saatlerini nasıl dolduracaklardır. Dolayısıyla Ziraat Fakültelerine yeni bir bölüm açılmasından önce salt güncel gereksinimlerle sınırlı olmayan bir geniş bakışla karar verilmeli, derin ve dikkatli analizler yapılmalıdır.

Abant İzzet Baysal Üniversitesi Ziraat ve Doğa Bilimleri Fakültesi'nde "Tohum Bilimleri ve Teknolojisi" adıyla bölüm açılmış, ancak bu yıl öğrenci talep edilmemiştir. Tohumculuk konusu, oldukça önemlidir. Böyle bir programın, lisans 
programı olarak değil, lisansüstü program olarak açılması düşünülebilirdi.....

Fakültelerimizin Öğrenci (Tercih) Yönlendirmesi İçin Uyguladıkları Yöntemler

2013 yılında kurulan Şırnak Üniversitesi Ziraat Fakültesi, 11 bölüm açmış, sadece bahçe bitkileri bölümüne 2014 - 2015 eğitim öğretim yılı için 31, 2015 - 2016 eğitim öğretim yılı için 21 öğrenci talep etmiştir. İlk tercih döneminde bölümü tercih eden öğrenci sayısı 2014-2015 için 4, 2015-2016 için 3'tür. Bu yüzden görsel ve yazılı basında bu yıl ek kontenjandan öğrenci tercihini artırabilmek özendirmek amacıyla burs verileceği duyurulmuştur. Şu habere bir bakınız:

IDIL HABER- Adaylar, 2015-2016 öğretim yılı için merkezi yerleştirmede boş kalan veya yerleştirilen adayların kayıt yaptırmaması nedeniyle boşalan yükseköğretim programlarının kontenjanlarına, ÖSYM tarafından yapılacak ek yerleştirmeler için tercihler 17 sinde başladı, 21 Ağustos'a kadar internet üzerinden bireysel olarak yapabilecekler.

Öğrenciler ek yerleştirme döneminde tercihlerini yaparken, Şırnak Üniversitesi Ziraat Fakültesini tercih yapmayı unutmasınlar. Ziraat fakültesini tercih eden öğrencilerin geri ödemesiz, faizsiz alacakları bursla eğitim boyunca ekonomi sıkıntı yaşamdan, alacağı kaliteli eğitimle birlikte eğitimde zirve yapacağı bir fakülteyi kaçırmamalarını tavsiye ederiz.

Ziraat Fakültesini, MF-2 180 puan alan her öğrenci tercih edebilecek. Ziraat fakültesini tercih eden öğrenciler ayda 1000 TL burs alabilecek. Burs eğitim boyunca devam edecek, geri ödemesiz olacak.

Ziraat fakültesini bitiren öğrenciler KPS sınavında 65 alarak yerleşebilecekler. Özel sektörde mühendis olarak çalışabilecekler. Mezun olan öğrenciler, fakültenin bünyesinde açılan yüksek lisans, doktora bölümlerinde akademik eğitimini yapabilecekler.

Ziraat fakültesi, 3 Prof., 9 Yrd. Doç. 8 araştırma görevleriyle eğitim konusunda eksikliği değil, fazlası olan fakülte sizi eğitime bekliyor (Anonim, 2015 c ve 2015 d).

Üniversitenin web sayfasında bu konu ile ilgili herhangi bir haber bulunmamaktadır. Bu haberler asparagas haber de olabilir! $\mathrm{Bu}$ durumda Şırnak Üniversitesi Ziraat Fakültesi'nin bir duyuru ile durumu açıklığa kavuşturması gerekmez miydi? Acaba, reklamın iyisi kötüsü olmaz anlayışı mı güdülmüştür. Bu habere göre tercih yapan öğrencilerin durumu ne olacaktır?

2012 yılında kurulan Abant izzet Baysal Üniversitesi Ziraat ve Doğa Bilimleri Fakültesi, 6 bölüm açmış, $2014-2015$ eğitim öğretim yılı için sadece tarla bitkileri bölümüne 31, 2015 2016 eğitim öğretim yılı için tarla bitkileri bölümüne 31 , bitki koruma bölümüne 41 , kanatı hayvan yetiştiriciliği bölümüne 26 öğrenci alacağını duyurmuştur. İlk tercih döneminde kanatlı hayvan yetiştiriciliği bölümünü tercih eden öğrenci sayısı sadece 5 'tir. Bu fakültede de - bu yıl ek kontenjandan- öğrenci tercihini artırabilmek amacıyla burs verileceği duyurulmuştur.

Kanatı Hayvan Yetiştiriciliği (Kanatı Bilimi ve Teknolojisi) Bölümü'nü tercih eden öğrenci arkadaşlar için ilgili sınavı kazanmaları durumunda, "kısmi zamanlı öğrenci" olarak, hem mesleki tecrübelerini artırmak hem de aylık ücret alma şansı olacaktır.

Kanatı Hayvan Yetiştiriciliği (Kanatıı Bilimi ve Teknolojisi) Bölümü'nü tercih eden öğrenci arkadaşlar için, çeşitli kuruluşlardan belli miktarlarda burs imkanları açılacaktır.

Bölümümüzde ek kontenjan için boşluk bulunmakta olup, tercihlerinizi ÖSYM'nin belirttiği tarihler arasında gerçekleştirebilir ve kaydınızı yaptırabilirsiniz.

17-21 Ağustos tarihleri ek kontenjan son kayıt tarihleridir. Kaçırmayınız. (Anonim 2015 e)

Öğrencilik de içinde 45 yıllık fakülte yaşamımda, başarısızığa ödül verildiğine ilk defa tanık oluyorum Üniversite sınavında ilk $1000, \quad 5000, \quad 10000$ 'e giren öğrencilerin ödüllendirilmesi son derece doğaldır. Bu sıralamaya giren öğrencilere 1000 TL değil daha fazla ödeme yapılması da beklenir. Ancak bu fakültelerimiz üniversite sınavında çok düşük puan almış, barajı kıl payı geçmiş (180 puan ve üzeri), üstelik ilk tercihlerinde bu bölümleri seçmemiş öğrencilere burs verileceğini açıklamışlardır!.....

\section{Sonuç}

Tarımsal yüksek öğretim, gerek fakülteler ölçeğinde, gerekse meslek yüksek okullarında bulunan tarımla ilgili programlar düzeyinde tam bir kaos içerisindedir.

Yukarıda açıklamaya çalıştığım konular acı bir gerçeği yüzümüze vurmaktadır. Gelecekte, bölümler dolayısı ile fakülteler öğrenci bulamayacaklardır. Fakültelerimiz ve 
bölümlerimiz bu gerçeği göz önüne alarak, son günlerin moda deyimiyle yol haritalarını gözden geçirmek zorundadırlar. Bu sorun, fakültelerin ve bölümlerin adını değiştirerek, yeni bölümler oluşturarak çözülebilecek bir sorun değildir (Çiftçi, 2013). Dahası dünyamızı ve ülkemizi kuşatan tarım/toprak/su temelli küresel sorundan bağımsız ele alınarak çözülebilmesi düşlerde bile olanaksız bir konudur....

Sonuç olarak şunu söyleyebilirim,

Her bölümün her ziraat fakültesinde bulunması mutlak bir zorunluluk değildir. Fakültenin bulunduğu, bölgenin gereksinim duyduğu bölümlerde eğitimin sürdürülmesi, o bölgenin gereksinim duymadığı bölümlerin kapatılması ve buna göre öğrenci istenmesi/alınması daha gerçekçi bir yol olarak gözükmektedir. Öğretim üyelerimiz, ne yazık ki lisansüstü program olabilecek konularda bile bölüm açma isteğini sürdürmektedirler. Bunu anlamak gerçekten zor! Başta da söylediğim gibi, bölümlerden mezun olacak gençlerin geleceklerinin de eş zamanlı düşünülmesi gerekmektedir.

Tarım Orman ve Su Ürünleri Konseyi, bu olumsuzlukların mutlak önüne geçmek zorundadır. Bu eğitsel/bilimsel/tarım-politik konu her aşamada dile getirmeli, yeni fakülte ve bölüm açılmasının önüne geçmelidir. Son yıllarda açıklanan işsizlik verilerine bir göz atmak yeter, bu savımızı kanıtlamaya. Artan işsizler arasında yükseköğretim mezunlarının oranı oldukça yüksektir. Bu da mezunları hesaba katılarak bir iş ve istihdam politikası oluşturulamadığını göstermektedir.

Ülkemizdeki illerin tamamı, bir hatta daha fazla üniversiteye, fakülteye ve meslek yüksekokuluna sahip olmayı istemektedir! Öğretim kurumları açıldığında; ilin ya da ilçenin nüfusu artacak, ekonomisi canlanacak, yeterli yurt ve barınma olanağı olmazsa ev sahiplerinin kira geliri artacaktır! Eğer açılacaksa da üniversiteler, fakülteler, meslek yüksekokulları; binaları, işlikleri, derslikleri, akademik ve idari kadroları, öğrencilerin kalabileceği yeterli yurtları ve sosyal tesisleriyle tümüyle hazır olduktan sonra açılmalıdır. Oysa uygulamada bu öğretim kurumları, bu donanımları olmadan açılmakta, gerek yöneticiler gerekse öğrenciler büyük zorluklarla karşı karşıya kalmaktadır (Çiftçi, 2009).

Yeni bir üniversite, fakülte açılırken gereksinim olup olmadığına bakılmamaktadır.
Idareciler, bu konuda karar verirken, üniversitelerin, fakültelerin ve bölümlerin Türkiye genelindeki durumuna bakmalı ve ona göre karar vermelidirler. Yüksek Öğretim Kurumunca bazı bölümlere yeter sayıda öğrenci tarafından tercih etmediği için kontenjan verilmemektedir. $\mathrm{Bu}$ çok yerinde bir uygulamadır, ama YÖK bu uygulama ve tercihi üniversite, fakülte ve bölüm açılırken dikkate alsa idi. Öğrencisi olmayan, öğrenci bulamayan bölümler, fakülteler yakın bir gelecekte ne yapacaktır? Akademik ve idari personel maaşları, bu bölümler ve fakültelerin binalarının bakımı, yakıt gideri vd. masrafları nasıl karşılanacaktır? Ülkemize mali açıdan ek bir yük de getirmeyecek midir böylesi bir yanlış tertip ve tercih?

Akman,1978, Yüksek Ziraat Enstitüsü'nün üniversite olması istemindeki nedenlerini şöyle açıklıyordu:

1. Bir Bakan'ın, Veteriner Fakültesinden bir profesörü profesörlük onuru ile bağdaşmayan bir göreve atamıştı ve ayrıca da adı geçen fakülte ile Ziraat Fakültesi hocaları üzerinde bazı tasarruflarda bulunacağı kuşkuları belirmişti. Bu gibi girişimlere her zaman ve her bakanda tanık olunabilir kuşkusu uyanmıştı.

2. 4936 sayılı Üniversiteler Kanunu gereğince Üniversite öğretim üyelerine "Üniversite Tazminatı" adı altında doçentlere 200, profesörlere 300 ve Ord. Profesörlere ise 400 lira olmak üzere verilen ödenek olarak ifade etmektedir. (Yüksek Ziraat Enstitüsü, Üniversiteler Kanununa tabi olmadığından öğretim üyeleri bu tazminattan yararlanamıyordu C.Y.Ç).

Bütün bunları anımsayınca, acaba günümüzde bu kadar fakülte açılmak istenmesini, yeni kadro ve unvanlar almak, habire bölüm çoğaltmak girişimlerini ise ek ders saatini doldurmak kaygısıyla açıklayabilir miyiz? Ne yazık ki bu olasılıklar oldukça yüksektir!

Polatlı ilçesi, il olma isteğini önce Türkçe, sonra da İngilizce olarak ilçe girişlerinde tabelalar halinde duyurmaya çalışmaktadır.

Ben de 15 yıldır yeni fakülte ve bölüm açılmaması gerekliliğini değişik ifadelerle hem yazılarımda hem de sunumlarımda dile getirmeye çalıştım. Bu kez Sevgili Ağabeyim emekli öğretmen Ümit SARIASLAN'ın sık kullandığı bir deyişle bu dileğimi tekrarlamak istiyorum. 
"Ekmek su hakkı için, bugünün ve gelecek kuşaklarının yaşamı ve yarınları için lütfen bin düşünüp bir eyleyelim".....

\section{Kaynaklar}

Anonim, 2012a. http//www.osym.gov.tr. 2012 ÖSYS Yükseköğretim Programlarının Merkezi Yerleştirmedeki En Küçük ve En Büyük Puanları

Anonim, 2012b. http//www.osym.gov.tr. 2012 ÖSYS Yükseköğretim Programlarına Ek Yerleştirme Kılavuzu

Anonim, 2014 a. http://dokuman.osym. gov.tr/pdfdokuman/2014/OSYS/Tercih/2014OSYSKONTKILAVUZU14072014.pdf. 2014 Öğrenci Seçme Ve Yerleştirme Sistemi (ÖSYS) Yükseköğretim Programları ve Kontenjanları Kılavuzu

Anonim, 2014 b. http://dokuman.osym.gov. tr/pdfdokuman/2014/OSYS/osys-ek/t-4baski15092014.pdf. 2014-ÖSYS Ek Yerleştirme Tercih Kılavuzu.

Anonim, 2015 a. http://dokuman.osym.gov .tr/pdfdokuman/2015/OSYS/2015-OSYS KONTKILAVUZU15072015.pdf. 2015 Öğrenci Seçme Ve Yerleştirme Sistemi (ÖSYS) Yükseköğretim Programları ve Kontenjanları Kılavuzu

Anonim, 2015 b. http://www.osym.gov.tr/belge/123623/2015-osys-ek-yerlestirme-kilavuz-ve-b asvuru-bilgileri.html. 2015-ÖSYS Ek Yerleştirme Tercih Kılavuzu

Anonim, 2015 c. http://www.sanalbasin.com/sirnakziraat-fakultesi-firsatini-kacirmayin-10589731/ erişim 28.08.2015

Anonim, 2015 d. http://www.idilhaber.com/ haber_detay.asp?haberID=1800\&HaberBasli k=ziraat-fakultesine-verilen-burs-geri-iyadeedilmiy

Anonim, 2015 e.http://zdf.ibu.edu.tr/index.php/tr/ boeluemler/kanatli-hayvan-yetistiriciligi erişim tarihi 28.08.2015

Çiftçi C.Y., 2002. "157. Yılında Zirai Öğretim”. Tarım ve Mühendislik Dergisi. TMMOB Ziraat Mühendisleri Odası Yayın Organı. Sayı: 64$652002,68-77$

Çiftçi C.Y., 2003. Türkiye'de Tarım Eğitiminin Bugünü ve Geleceği. Türkiye 5. Tarla Bitkileri Kongresi. 13-17 Ekim 2003 Diyarbakır. I. Cilt 8- 15

Çiftçi C.Y., 2004. Geçmişten Günümüze Türkiye'de Ziraat Mühendisliği Eğitiminin Değişimi. TMMO, Z.M.O. Uluslar Arası Sempozyum. 50. Yıl Kutlama ve Tarım Haftası Etkinlikleri Tarım ve Mühendislik. 12 - 16 Ocak 2004. 304 - 332.Ankara
Eriş A., Çiftçi C.Y., İsmailçelebioğlu N., Direk M., 2005. Tarımsal Yükseköğrenim”. TMMOB Ziraat Mühendisleri Odası, Türkiye Ziraat Mühendisliği 6.Teknik Kongresi (3-7 Ocak 2005) 1075- 1097

Çiftçi, C.Y., 2007. Türkiye'de Bulunan Ziraat Fakültelerinin 2006 Yılındaki Durumu. Tarım ve Mühendislik Dergisi. TMMOB Ziraat Mühendisleri Odası Yayın Organı. Sayı: 7879. 2007, 86-94

Çiftçi, C.Y., 2007. Türkiye Ziraat Mühendisliği Eğitiminde (1930 - 2007) Uygulanan Yönetmelikler İle Ziraat Mühendisliği Eğitiminin Sorunları ve Çözüm Önerileri. TÜRKTARıM Tarım ve Köyişleri Bakanlığı Dergisi, Mart - Nisan 2007, Sayı 174, 18 - 32. ANKARA

Çiftçi, C.Y., 2009. Türkiye'de Bulunan Devlet ve Vakıf Üniversiteleri. Ankara Üniversitesi Ziraat Fakültesi Yayın No 1498, Bilimsel Araştırmalar ve İncelemeler 822. 41 s. Ankara

Çiftçi C.Y., Ortaş İ., Çelik S., Kendir H., Sağlam S., 2010. Tarımsal Yükseköğretim Programında Değişimler ve Sorunlar (Sunulu Bildiri). TMMOB Ziraat Mühendisleri Odası Ziraat Mühendisliği VII. Teknik Kongresi (11-15 Ocak 2010) Bildiriler Kitabı II, 1161 - 1180 Ankara

Çiftçi C.Y., 2012. Türkiye'de Tarımsal Yükseköğretim. TÜRKTOB Türkiye Tohumcular Birliği Dergisi Yıl 1, Sayı 2. 1013. Ankara

Çiftçi C.Y., Öztürk H.S., 2012. Ziraat Fakültelerindeki Eğitim Sorunları ve Çözüm Önerileri. Stratejik Yönetim Dergisi. Nisan Mayıs Haziran 2012. Yıl 1, Sayı 3, 50 - 57. Ankara

Çiftçi C.Y., 2012. Artık Hiçbir İlde Ziraat Fakültesi Açılmamalı Tarım ve Mühendislik. TMMOB Ziraat Mühendisleri Odası Yayın Organı. ISSN-1300-0071. Sayı 99-100/2012. $32-36$ s. Ankara

Çiftçi C.Y. 2013. 165. Yılında Tarımsal Yükseköğretim. Ziraat Mühendisliği. Türk Ziraat Yüksek Mühendisleri Birliği Hakemli Yayın Organı. (Temmuz- Aralık 2012) Sayı: 359, 4 - 17. Ankara

Çiftçi C.Y., 2013 Tarımsal Yükseköğretim Nereye Gidiyor. Tarım ve Mühendislik. TMMOB Ziraat Mühendisleri Odası Yayın Organı. ISSN1300-0071. Sayı 104/2013. 40 - 56 s. Ankara

Çiftçi C.Y. ve Benlioğlu, B. 2014. Türkiye'de Tarımsal Öğretimle İlgili Meslek Yüksekokulları. Ziraat Mühendisliği Dergisi. Türk Ziraat Yüksek Mühendisleri Birliği Yayın Organı. ISSN1301-0891. Sayı 361. 4 - 12. Ankara 